Archive for

Organic Chemistry

Arkivoc 2020, part iii, 136-151

\title{
Rational design and regioselective synthesis of conformationally restricted furan- derived ligands as potential anti-malarial agents
}

\author{
Marius K. Mutorwa, ${ }^{a}$ Iviwe Nokalipa, ${ }^{a}$ Delia C. Tanner, ${ }^{b}$ Gregory L. Blatch, ${ }^{b, c}$ \\ Kevin A. Lobb, ${ }^{a, c}$ Rosalyn Klein, ${ }^{a, c}$ and Perry T. Kaye ${ }^{a, c} *$
}

${ }^{a}$ Department of Chemistry, ${ }^{b}$ Biomedical Biotechnology Research Unit and Department of Biochemistry and Microbiology and ${ }^{C}$ Centre for Chemico- and Biomedicinal Research, Rhodes University, Grahamstown, 6140, South Africa

E-mail: P.Kaye@ru.ac.za.

Received 06-30-2020

Accepted 01-23-2021

Published on line 02-05-2021

\section{Abstract}

Substituted 3-furanomethyl phosphate esters and their corresponding phosphoric acids have been prepared as conformationally restricted analogues of DOXP, the natural substrate for Plasmodium falciparum 1-deoxyD-xylulose-5-phosphate reductoisomerase (PfDXR), and fosmidomycin, an established inhibitor. Saturation Transfer Difference (STD) NMR analysis and in silico docking data suggest the potential of such compounds as PfDXR inhibitors.

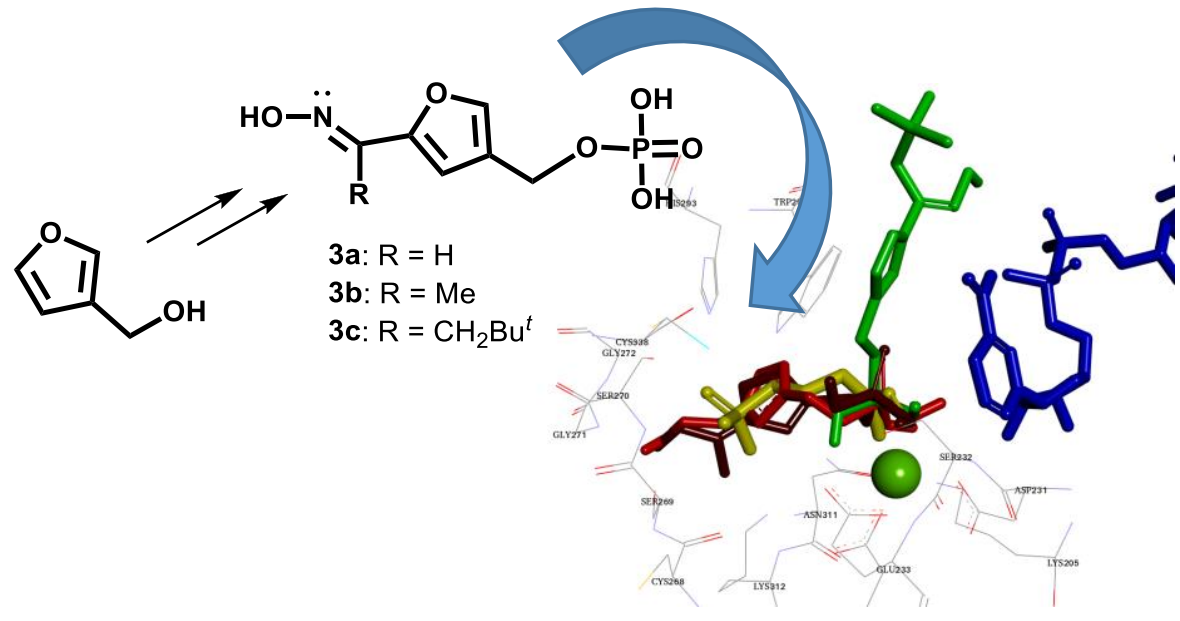

Keywords: Furan derivatives, 1-deoxy-D-xylulose-5-phosphate (DOXP), fosmidomycin, PfDXR inhibitors, in silico docking, STD NMR. 


\section{Introduction}

Malaria presents major and apparently continuing health challenges worldwide - particularly in Sub-Saharan Africa. ${ }^{1}$ The situation is compounded by the emergence of drug-resistant Plasmodium falciparum (Pf) parasites, ${ }^{2-3}$ insecticide-resistant mosquitoes ${ }^{4}$ and the increased susceptibility to infection in HIV-positive individuals..$^{5-7}$ Quinolines, anti-folates, hydroxynapthoquinones, antibiotics and, latterly, artemisinins have all found use as anti-malarial agents. ${ }^{8}$ Artemisinin-based Combination Therapy (ACT), ${ }^{9}$ involving the use artemisinins (with short plasma half-lives) in combination with long-acting, anti-malarial drugs, has proved effective but expensive.

Various human pathogens, ${ }^{10,11}$ including $P$. falciparum, make exclusive use of the non-mevalonate 1deoxy-D-xylulose-5-phosphate (DOXP)/2-C-methyl-D-erythritol-4-phosphate (MEP) pathway for the biosynthesis of isoprenoids. 1-Deoxy-D-xylulose-5-phosphate reductoisomerase (DXR), a key enzyme in this pathway, has been validated as a suitable target for therapeutic intervention, ${ }^{11}$ and the antibiotic fosmidomycin 1 and its acetyl derivative FR900098 ${ }^{11,13}$ have been shown to inhibit the enzyme. Numerous analogues of these compounds have been developed, ${ }^{14}$ and we have reported the synthesis and evaluation of phosphonated $\mathrm{N}$-aryl- and $\mathrm{N}$-heteroarylcarboxamides and ( $\mathrm{N}$-arylcarbamoyl)alkylphosphonic acid derivatives ${ }^{15,16}$ as fosmidomycin analogues, $N$-substituted phosphoramidic acid esters as "reverse" fosmidomycin analogues ${ }^{17}$ and $\mathrm{N}$-benzylated phosphoramidic acid derivatives as FR900098 analogues. ${ }^{18}$ Some approaches by other groups have focussed on the development of structural analogues of the natural substrate, DOXP 2, as potential DXR inhibitors. ${ }^{19-21}$ We now report the regioselective synthesis of conformationally constrained furan-derived ligands, which incorporate structural features of both DOXP and fosmidomycin.<smiles>O=CN(O)CCCP(=O)(O)O</smiles>

Fosmidomycin 1<smiles>O=CC(O)[C@H](O)COP(=O)(O)O</smiles>

DOXP 2

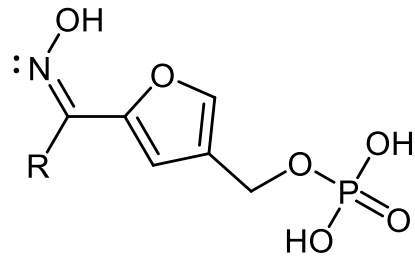

3a: $\mathrm{R}=\mathrm{H}$

3b: $\mathrm{R}=\mathrm{Me}$

3c: $\mathrm{R}=\mathrm{CH}_{2} \mathrm{Bu}^{t}$

Figure 1. Structures of fosmidomycin 1, DOXP 2 and the targeted ligands 3.

\section{Results and Discussion}

Earlier in silico modelling, ${ }^{22}$ under rigid conditions using Autodock $4.0,{ }^{23}$ indicated the capacity of the furan derivative $\mathbf{3 a}$ to adopt a stable conformation similar to fosmidomycin $\mathbf{1}$ in the active-site of a, then available, $X$-ray structure of $E c \mathrm{DXR}(2 \mathrm{EGH}) .{ }^{24}$ Figure 2 illustrates the potential of the furan and Z-oxime oxygen atoms to coordinate the divalent $\mathrm{Mg}^{2+}$ cation via a six-membered chelate. (With the E-oxime a five-membered metal chelate may be envisaged involving the furan oxygen and oxime nitrogen atoms.) While the dihydro- and tetrahydrofuran analogues have exhibited similar alignment with DOXP 2, our synthetic efforts have been focussed, initially, on the furan derivatives 3a-c. 


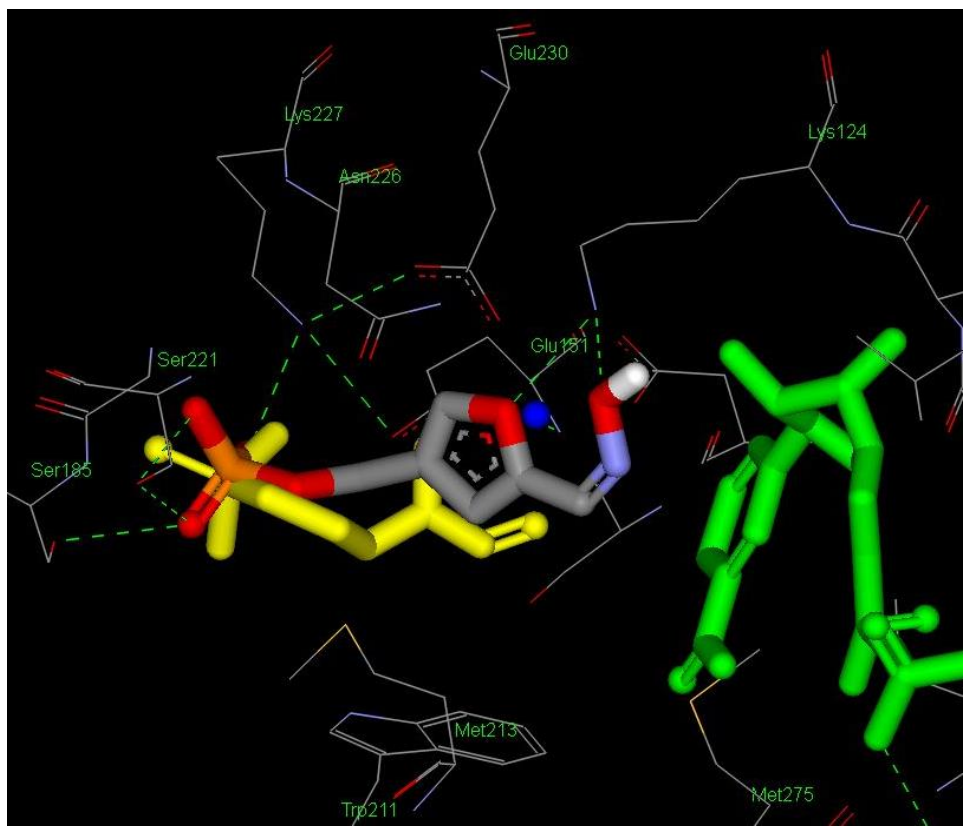

Figure 2. Initial rigid docking, using Autodock, ${ }^{23}$ of ligand 3a in the EcDXR active-site (2EGH), ${ }^{24}$ illustrating hydrogen-bonding of the ligand with active-site residues. The crystal structure conformation of fosmidomycin $\mathbf{1}$ is coloured yellow, protein active-site residues are shown in wire-frame coloured by atom type, NADPH is coloured green, $\mathrm{Mg}^{2+}$ is shown as a blue sphere and the ligand $\mathbf{3 a}$ is coloured by atom type. Hydrogen bonds are shown as green dashed lines.

Readily available 3-furanmethanol 4 appeared to be an appropriate substrate for the targeted 2,4disubstituted furan derivatives 3a-c and and 11a-c (Scheme 1). However, electrophilic substitution is favoured at both of the $\alpha$-positions (C-2 and C-5) in furan ${ }^{25,26}$ and regioselective C-5 acylation of 3-furanmethanol 4 (C-2 in the product!) was clearly desirable. Moreover, since the initial approach was planned to involve a lithiationacylation sequence, protection of the hydroxyl group in compound $\mathbf{4}$ was considered necessary. Tritylation was deemed a promising solution to both challenges since it would protect the hydroxyl group and the steric bulk of the resulting 3-(trityloxymethyl) group was expected to hinder competitive acylation at C-2 thus directing substitution to $\mathrm{C}-5$. Reaction of 3-furanmethanol 4 with trityl chloride in the presence of excess triethylamine and a catalytic quantity of 4-dimethylaminopyridine (DMAP) afforded the protected intermediate $\mathbf{5}$ in $72 \%$ yield (Scheme 1).

In addition to introducing formyl (as in fosmidomycin 1) and acetyl groups (as in FR900098), introduction of the 3,3-dimethylbutanoyl group was planned in order to explore the capacity of unoccupied hydrophobic cavities in the DXR-active site to accommodate the bulky tert-butyl group. Several methods for acylating the furan moiety of the tritylated derivative $\mathbf{5}$ were explored. The first, which involved treatment of the tritylated derivative $\mathbf{5}$ with $n$-butyllithium followed by reaction with DMF, resulted in a mixture shown by NMR analysis to contain the isomeric aldehydes $6 a$ and $7 a$. Semi-preparative HPLC afforded the desired regioisomer $6 a$ as the major product, but in only $12 \%$ yield. Vilsmeier-Haak formylation ${ }^{27}$ of the tritylated derivative 5 using phosphoryl chloride and DMF, however, furnished the desired aldehyde 6a as the major product in $64 \%$ yield. The 5 (formerly 2 )- $\mathrm{H}$ signal is clearly evident at $6.74 \mathrm{ppm}$ in the ${ }^{1} \mathrm{H}$ NMR spectrum of compound $6 \mathrm{a}$ but is absent in the spectrum of the regioisomer $7 \mathrm{a}$, which was isolated in a yield of only $2.4 \%$. 
Friedel-Crafts methodology 28,29 was employed to access the 5-acetyl- and 5-(3,3-dimethylbutanoyl) analogues $\mathbf{6 b}$ and $\mathbf{6 c}$, respectively. While aluminium trichloride is commonly used as the Lewis acid catalyst in such reactions, it has been reported to induce polymerisation of furan derivatives ${ }^{30}$ and attention was consequently given to the use of tin tetrachloride $\left(\mathrm{SnCl}_{4}\right)$ and zinc chloride $\left(\mathrm{ZnCl}_{2}\right)$ as alternative catalysts. ${ }^{31,32}$ Thus, the tritylated furan derivative 5 was reacted with acetic anhydride ${ }^{33}$ and with 3,3-dimethylbutanoyl chloride using $\mathrm{SnCl}_{4}$ and $\mathrm{ZnCl}_{2}$ to afford the required acylated derivatives $6 \mathbf{b}$ and $\mathbf{6 c}$ as the major products; the regio-directing effect of the 3-(trityloxymethyl) group was certainly evident with the unwanted 2-substituted regioisomers being limited to trace quantities $(<3 \%)$. The reactions were conducted initially at $0{ }^{\circ} \mathrm{C}$ and then $40{ }^{\circ} \mathrm{C}$, thus avoiding electrophilic substitution of the phenyl rings, marginally better yields being obtained for $6 \mathrm{~b}$ and $6 \mathrm{c}$, respectively with $\mathrm{SnCl}_{4}$ (64 and 56\%) than with $\mathrm{ZnCl}_{2}$ (37 and 33\%).

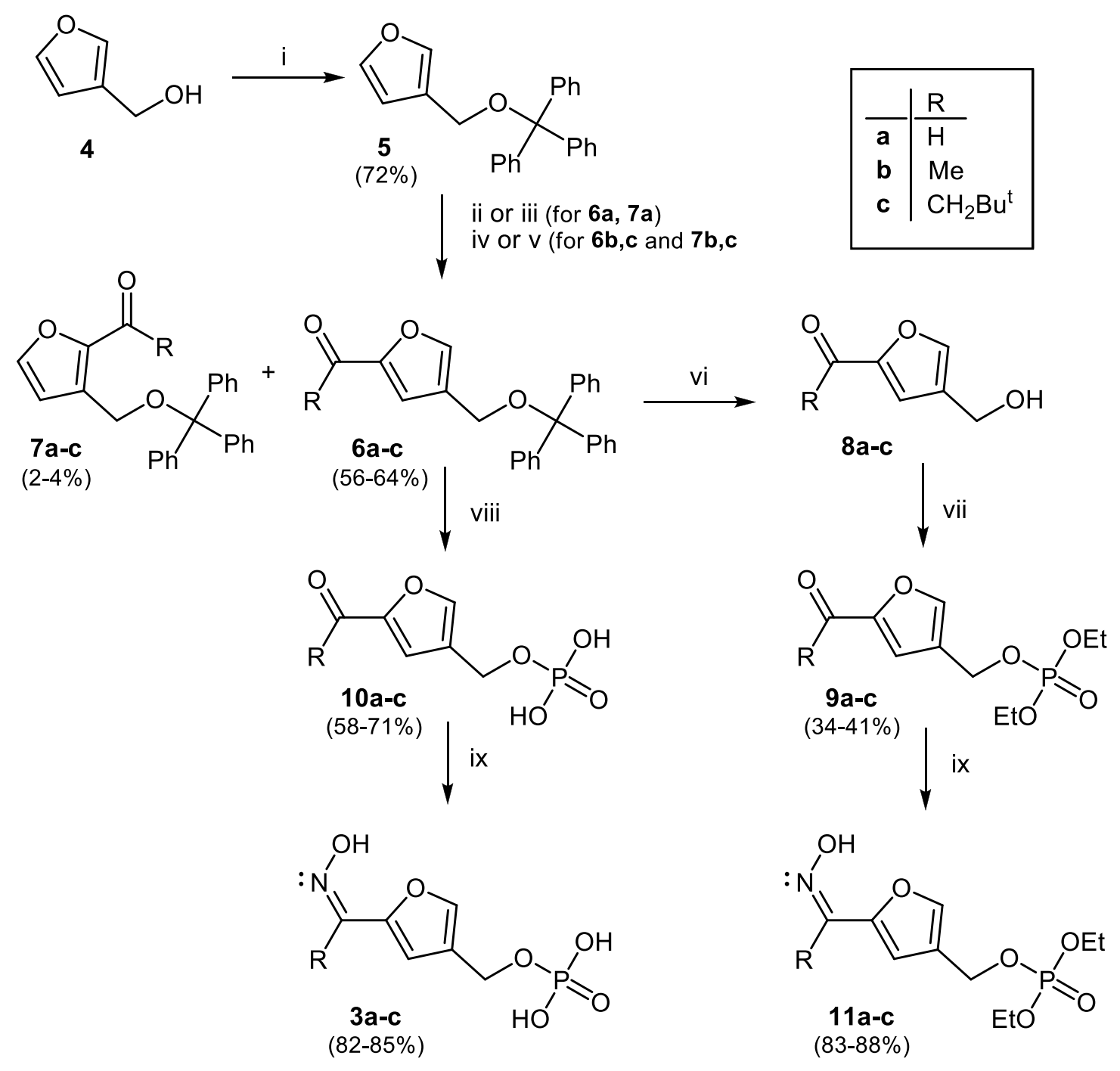

\section{Scheme 1}

Reagents and reaction conditions: i) $\mathrm{Ph}_{3} \mathrm{CCl}, \mathrm{Et}{ }_{3} \mathrm{~N}, \mathrm{DMAP}, \mathrm{THF}, 80{ }^{\circ} \mathrm{C}, 15 \mathrm{~h}, \mathrm{~N}_{2}$; ii) $n$-BuLi, THF, $-30{ }^{\circ} \mathrm{C}, 4 \mathrm{~h}, \mathrm{~N}_{2}$ then DMF, $-30{ }^{\circ} \mathrm{C}, 2 \mathrm{~h}$, r.t., 2 h.; iii) $\mathrm{POCl}_{3}, \mathrm{DMF}, 0{ }^{\circ} \mathrm{C}$ for $2 \mathrm{~h}, 65^{\circ} \mathrm{C}$ for $1 \mathrm{~h}$ then $\mathrm{H}_{2} \mathrm{O} / \mathrm{NaOH}$; iv) $\mathrm{Ac}_{2} \mathrm{O}$ or 3,3dimethylbutanoyl chloride, $\mathrm{SnCl}_{4}, 0^{\circ} \mathrm{C}$ for $1 \mathrm{~h}, 40{ }^{\circ} \mathrm{C}$ for $4 \mathrm{~h}, \mathrm{~N}_{2}$; v) $\mathrm{Ac}_{2} \mathrm{O}$ or 3,3-dimethylbutanoyl chloride, $\mathrm{ZnCl}_{2}, 0^{\circ} \mathrm{C}$ for $1 \mathrm{~h}, 40{ }^{\circ} \mathrm{C}$ for $8 \mathrm{~h}, \mathrm{~N}_{2}$; vi) $\mathrm{HCOOH} / \mathrm{THF} / \mathrm{H}_{2} \mathrm{O}$ [1:1:0.1 v/v], $50{ }^{\circ} \mathrm{C}, 2 \mathrm{~h}$; vii) diethyl chlorophosphate, pyridine, $0^{\circ} \mathrm{C}, 1 \mathrm{~h}$, r.t., overnight; viii) $\mathrm{H}_{3} \mathrm{PO}_{4} / \mathrm{THF}(1: 1 \mathrm{v} / \mathrm{v})$, r.t., $2 \mathrm{~d}$; ix) $\mathrm{NH}_{2} \mathrm{OH} . \mathrm{HCl}, \mathrm{NaOAc}$, EtOH, reflux, $1 \mathrm{~h}$. 
While various methods have been reported for removing the trityl protecting group, ${ }^{34-36}$ we elected to use mild acid hydrolytic conditions, ${ }^{37}$ involving treatment of compounds 6 a-c with formic acid in aqueous methanol for two hours at $50{ }^{\circ} \mathrm{C}$. The resulting primary alcohols $8 \mathrm{a}-\mathrm{c}$ were used without further purification; reaction with diethyl chlorophosphate in pyridine gave the corresponding phosphate esters 9a-c in $71-74 \%$ yield. The dihydrogen phosphate analogues $10 \mathrm{a}-\mathrm{c}$, on the other hand, were accessed in moderate yields (58$65 \%)$ by subjecting compounds 6a-c to tandem de-tritylation and phosphorylation using a mixture of $\mathrm{H}_{3} \mathrm{PO}_{4}$ and THF (1:1 v/v). The presence of the phosphate moiety in compounds (9) and (10) is confirmed by the splitting of ${ }^{1} \mathrm{H}$ and ${ }^{13} \mathrm{C}$ NMR signals from ${ }^{31} \mathrm{P}$ coupling with other proximate nuclei.

The final phase in our approach to the desired DOXP analogues involved oximation of the carbonyl compounds (9) and (10). While various oximation methodologies have been developed, ${ }^{38-40}$ we followed the classical method, ${ }^{41}$ which involved treating compounds $9 a-c$ and $10 a-c$ with an ethanolic solution of hydroxylamine hydrochloride in the presence of a catalytic quantity of sodium acetate. The corresponding, novel oximes 11a-c and 3a-c were isolated in good yields (87-96\%) and were fully characterised. The phosphate esters 11a-c might be expected to act as pro-drugs with better membrane permeability than their dihydrogen phosphate analogues 3a-c, to which they could be hydrolysed in vivo by esterases.

Extensive in silico docking studies of compounds $\mathbf{3 a - c}$ and $\mathbf{1 0 a - c}$ [including all possible (de)protonation states and $E / Z$ oxime geometries], and the phosphate esters 11a-c and 9a-c in ECDXR and/or PfDXR active sites have been undertaken. Autodock $4.2^{23}$ docking in the initially available EcDXR X-ray structure $\left(2 \mathrm{EGH}^{24}\right) \mathrm{had}^{2}$ revealed that the most favourable conformation adopted by the formyl derivative $\mathbf{3 a}$ within the active-site exhibited hydrogen-bonding interactions with the rigidly held proximal amino acid residues, Lys 124, Glu151, Ser185, Ser221, Lys227 and Glu230. Compound $\mathbf{3 a}$ and its acetyl derivative $\mathbf{3 b}$ exhibited comparable, respective binding affinities $\left(-10.84\right.$ and $\left.-10.20 \mathrm{Kcal}^{\mathrm{mol}}{ }^{-1}\right)$ and ligand efficiencies $(-0.77$ and -0.68$)$. The furan ring not only restricts conformational flexibility between the phosphate- and metal-binding sites, but the endocyclic oxygen appears to exhibit a hydrogen-bonding interaction with Lys 124 . The 3,3-dimethylbutanoyl analogue 3c, however, appeared to be too bulky to be accommodated within the active-site, with the tertbutyl group extending well beyond the metal-binding site and resulting in a ca. $50 \%$ reduction in binding affinity (-5.89 $\left.\mathrm{Kcal}^{\mathrm{mol}}{ }^{-1}\right)$ and ligand efficiency (-0.31).

In more detailed studies of the effect of steric bulk in determining the access and binding of ligands to EcDXR and PfDXR active sites, Autodock $4.2^{23}$ and Autodock Vina ${ }^{42}$ were both used and the proximal receptor residues were set to be flexible. In addition, various protonation and stereochemical ( $E$ - and Z-oxime) options were considered for each of the compounds 3a-3c. Each of the resulting ligand structures was docked against

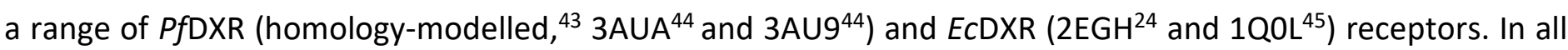
cases, binding of the potential pro-drugs 11a-c was, unsurprisingly, less favourable than for the potential DXR inhibitors 3a-c. Interestingly, in terms of binding energy, ligand binding to the ECDXR structures was favoured over the PfDXR structures. With Autodock $4.2^{23}$ docking, the ligand poses proved highly sensitive to the protonation state and the $E / Z$ geometry of the oxime moiety. Moreover, as evidenced by the relative binding energies (illustrated graphically in the Supplementary Information file), there was little consistency in ligand poses through the series. However, the binding energy data indicates that the $\mathbf{3 a}(R=H)$ and $\mathbf{3 b}(R=M e)$ species bind preferentially to the PfDXR structures, while the $3 c\left(R=\mathrm{CH}_{2} \mathrm{Bu}^{t}\right)$ species exhibits a preference for EcDXR (data tabulated and illustrated graphically in the Supplementary Information file). Given their structural similarity to DOXP, the 2-acylated furan derivatives $10 a-c$ and their diethyl ester analogues 9a-c were also docked against the selected enzyme targets. In the light of these studies, some general observations can be made. 
i) Autotock Vina ${ }^{42}$ docking to a rigid receptor gave consistently weak binding energies indicative of poor binding for all the ligand systems examined. The QuickVina- $W^{46}$ and Autodock Vina ${ }^{42}$ results for binding to a flexible receptor generally reflect significantly stronger binding and the corresponding data sets are consistent with each other.

ii) It is apparent that while $\mathbf{3 a}$ and $\mathbf{3 b}$ bind well to both PfDXR and EcDXR receptors, $\mathbf{3 c}$ having the greatest steric bulk binds better to EcDXR (and to the PfDXR homology model ${ }^{43}$ which is based on an EcDXR template).

iii) Interestingly, $\mathbf{3 a}$ and $\mathbf{3 b}$ exhibit "reverse" binding in the active site of the PfDXR structure 3AU9_A, ${ }^{44}$ in the sense that, in each of the ligands, the phosphate moiety, rather than the oxime moiety, is located close to the magnesium cation (Figure 3). In contrast, $3 c$ binds outside of the active site with weak binding affinity (-5.0 $\mathrm{Kcal} / \mathrm{mol})$. Other docking poses show 3c penetrating a cleft in the protein to allow the phosphate moiety to coordinate to the $\mathrm{Mg}^{2+}$ cation, albeit with even weaker binding affinity $(-4.6 \mathrm{Kcal} / \mathrm{mol})$. Ligands $3 \mathbf{a}$ and $3 \mathbf{b}$, on the other hand, exhibit good binding energies (-8.1 and $-8.5 \mathrm{Kcal}^{\mathrm{mol}}{ }^{-1}$, respectively). These binding energies should be seen in the context of the corresponding values for the known inhibitors, FR900098 and fosmidomycin 1, to 3AU9_A $A^{44}\left(-8.2 \mathrm{Kcal} \mathrm{mol}^{-1}\right.$ in both instances).

iv) Similar orientation patterns emerge (Figure 4) for binding to the EcDXR receptor $2 \mathrm{EGH} \mathrm{B}^{24}$ with $\mathbf{3 a}$ and $\mathbf{3 b}$ almost perfectly overlaid in a "reverse" orientation. However 3c now binds in the "normal" orientation, in that the oxime moiety binds close to the $\mathrm{Mg}^{2+}$ cation. It is also apparent, however, that all three of the ligands 3a-c bind orthogonally to the co-crystallized ligand, fosmidomycin 1, but ligand $3 c$ exhibits the strongest binding affinity for this receptor (-9.6s Kcal.mol ${ }^{-1}$ compared to -8.0 and $-8.4 \mathrm{Kcal}^{\mathrm{mol}} \mathbf{m}^{-1}$ for $\mathbf{3 a}$ and $\mathbf{3 b}$, respectively). Again, this is in the context of the binding of FR900098 and fosmidomycin 1 to 2 EGH_B ${ }^{24}(-8.2$ and -7.3 Kcal. ol $^{-1}$, respectively).

v) Weak docking scores were observed for the phosphate esters 9a-c across all targets. While the structural variants for 10c exhibit good binding to the EcDXR targets (and the PfDXR homology model ${ }^{43}$ ), they bind poorly to the PfDXR targets (e.g., $-7.3 \mathrm{Kcal} \mathrm{mol}^{-1}$ to PfDXR 3AU9_B ${ }^{44}$ ). The 2-formyl and 2-acetyl DOXP analogues 10a and 10b, however, exhibit good binding scores across all targets - particularly to PfDXR targets. In fact, their binding affinities for PfDXR 3AU9_B ${ }^{44}(\mathbf{1 0 a},-8.1 ; \mathbf{1 0 b},-8.4)$ are comparable with that of the natural enzyme substrate, DOXP (-8.5 Kcal.mol-1). Moreover, in terms of pose, the docking of DOXP and 10a-b to 3AU9_B, ${ }^{44}$ for example, clearly matches the fosmidomycin 1 pose in the crystal structure, as illustrated in Figure 5. Ligand 10c, however, is too large to be accommodated within the active site, and its best pose penetrates through the enzyme structure to coordinate the $\mathrm{Mg}^{2+}$ cation. 


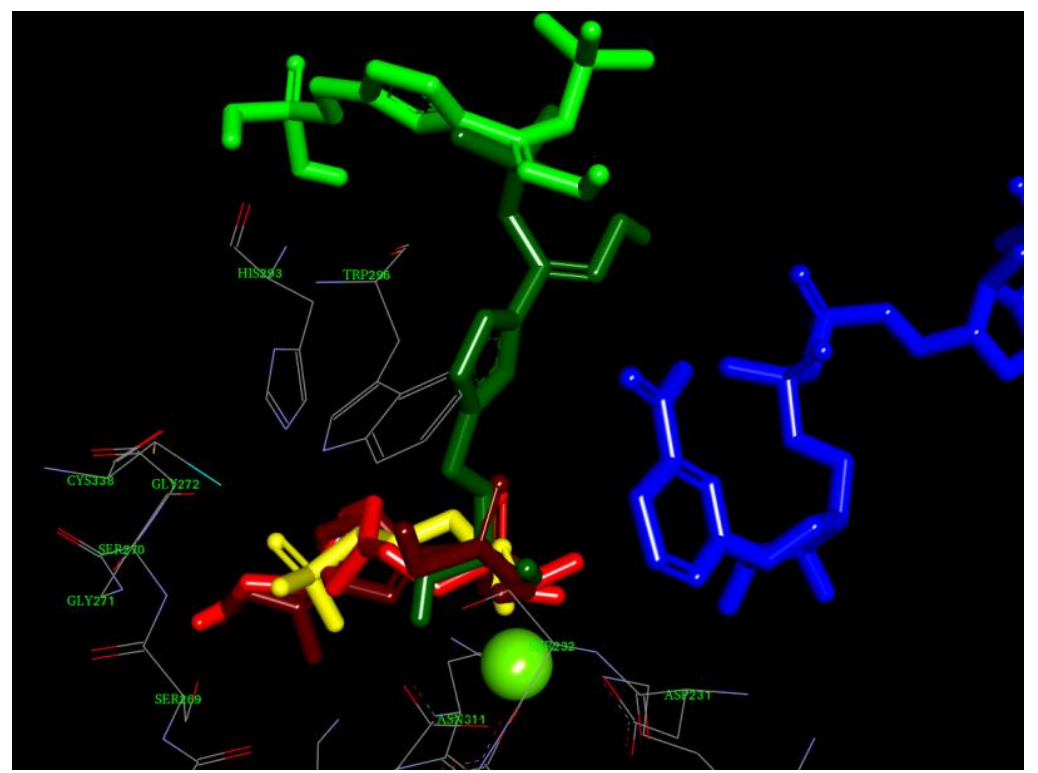

Figure 3. Best binding poses of $\mathbf{3 a}$ (red) and $\mathbf{3 b}$ (brown) to the PfDXR structure 3AU9_A ${ }^{44}$ showing reverse binding (with phosphate close to the $\mathrm{Mg}^{2+}$ cation) relative to fosmidomycin $\mathbf{1}$ yellow. 3c binds externally (light green) with higher energy poses penetrating the active site (dark green). The cofactor is shown in blue and the Mg cation as a sphere.

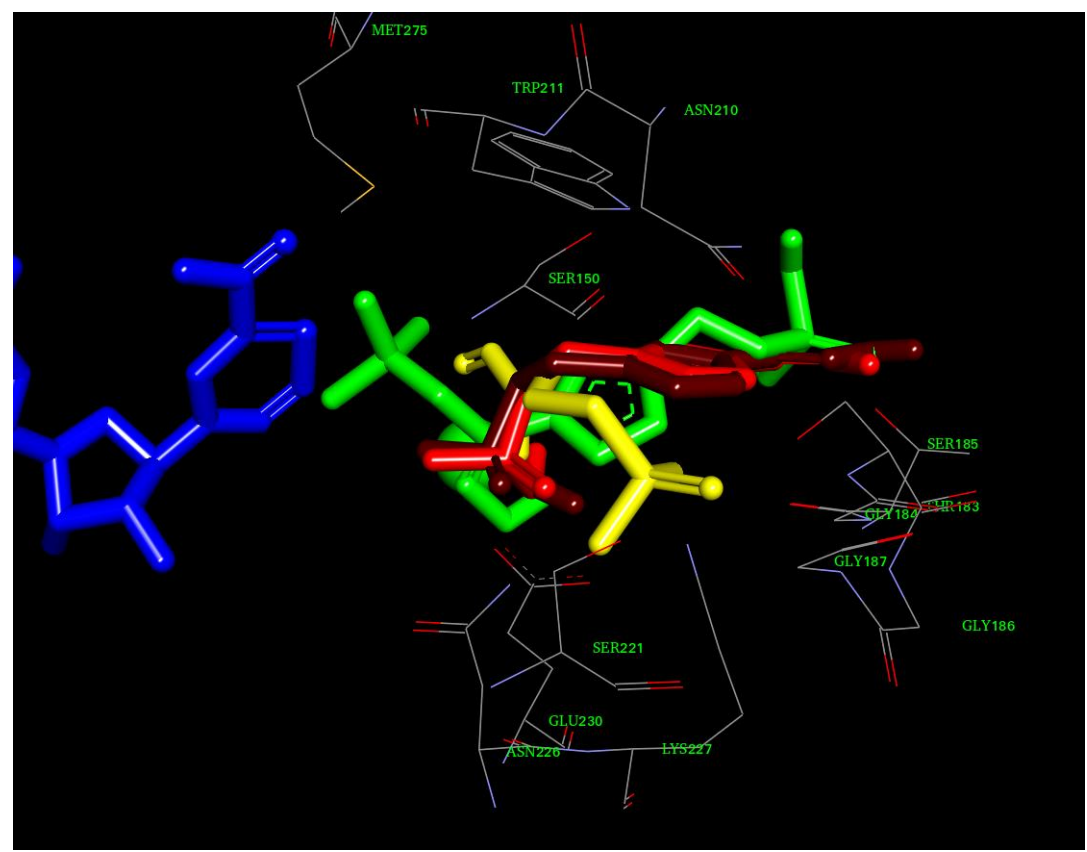

Figure 4. Best binding poses of $\mathbf{3 a}$ (red) and $\mathbf{3 b}$ (brown) to the EcDXR structure 2EGH_B ${ }^{24}$ showing "reverse" binding (with phosphate close to the $\mathrm{Mg}^{2+}$ cation). 3c (green) interacts with the $\mathrm{Mg}$ (behind) in a similar manner to fosmidomycin $\mathbf{1}$ (yellow). The cofactor is shown in blue and the $\mathrm{Mg}^{2+}$ cation (behind) as a green sphere. 


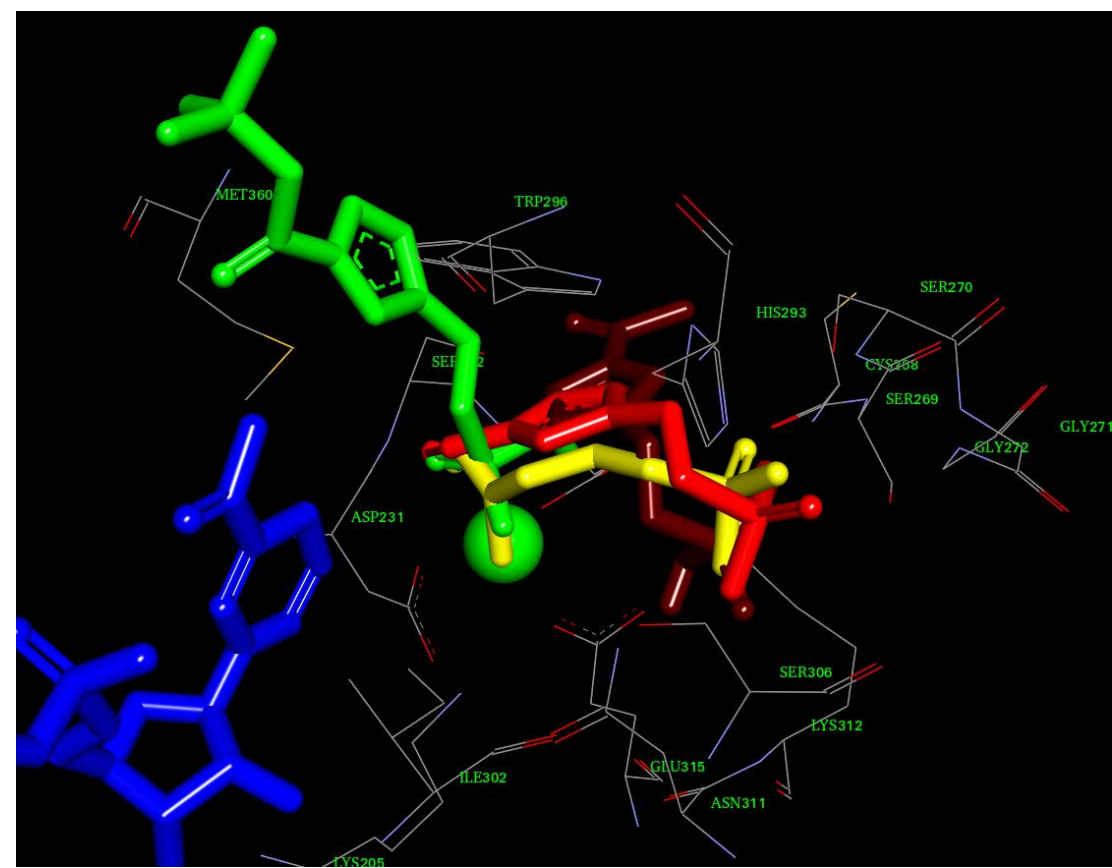

Figure 5. Best binding poses of $10 \mathrm{a}$ (red), $\mathbf{1 0 b}$ (brown) and $10 \mathrm{c}$ (green) to the PfDXR structure 3AU9_B. ${ }^{44} 10 \mathrm{a}$ and 10b, together with DOXP (not shown) bind in an arrangement similar to fosmidomycin 1 (yellow). 10c penetrates through to the active site. The cofactor is shown in blue and the $\mathrm{Mg}^{2+}$ cation as a sphere.

\section{Conclusions}

A series of novel (2-subsituted furan-4-yl)methyl dihydrogen phosphates (3a-c) and (10a-c) and their corresponding diethyl derivatives (11a-c) and (9a-c) have been prepared regioselectively. The formyl and acetyl derivatives $\mathbf{3} \mathbf{a}$ and $\mathbf{3} \mathbf{b}$ had earlier been subjected ${ }^{22}$ to Saturation Transfer Difference (STD) NMR binding studies using the then available ECDXR enzyme; both compounds gave positive STD results (illustrated in the Supporting Information file). While the STD NMR data does not preclude the possibility of allosteric or noncompetitive binding, these results are clearly consistent with the significant in silico binding data of the oximes $\mathbf{3 a}$ and $\mathbf{3 b}$ and the DOXP analogues $\mathbf{1 0 a}$ and $\mathbf{1 0 b}$ in PfDXR enzyme active sites. These results, coupled with the possibility of the corresponding diethyl phosphate esters (9) and (11) serving as potential pro-drugs, will encourage future research on the synthesis of dihydro- and tetrahydrofuran analogues and the capacity of such conformationally constrained ligands to inhibit the action of the PfDXR enzyme and, hence, the growth of the $P$. falciparum parasite. The PfDXR enzyme is now readily over-expressed and purified using heterologous expression systems, ${ }^{47}$ enabling the future screening of these furan derivatives for novel inhibitors of this antimalarial drug target.

\section{Experimental Section}

General. NMR spectra were recorded on Bruker AVANCE 400 or BIOSPIN $600 \mathrm{MHz}$ spectrometers in $\mathrm{CDCl}_{3}$, $\mathrm{DMSO}-d_{6}$ or $\mathrm{CD}_{3} \mathrm{OD}$, and were calibrated using solvent signals. Melting points were measured using a hot-stage apparatus and are uncorrected. High-resolution mass spectra (HRMS) were recorded on a Waters API Q-TOF 
Ultima spectrometer (University of Stellenbosch, Stellenbosch, South Africa) and elemental analyses were obtained on a Vario Elemental Microtube EL III analyser. STD NMR and computer modelling protocols have been published previously. ${ }^{16}$ Representative NMR spectra are provided in the Supporting Information.

3-[(Trityloxy)methyl]furan (5). A solution of triphenylmethyl chloride (6.00 g, $21 \mathrm{mmol}), 3$-furanmethanol (4) $(2.00 \mathrm{~g}, 20.4 \mathrm{mmol})$, triethylamine $(4.5 \mathrm{~mL}, 3.24 \mathrm{~g}, 32 \mathrm{mmol})$ and DMAP $(0.61 \mathrm{~g}, 5.0 \mathrm{mmol})$ in THF $(30 \mathrm{~mL}) \mathrm{was}$ stirred under $\mathrm{N}_{2}$ at $80^{\circ} \mathrm{C}$ for 15 hours. The solvent was evaporated in vacuo and the residue dissolved in EtOAC $(100 \mathrm{~mL})$. The organic phase was washed sequentially with water $(2 \times 50 \mathrm{~mL})$ and brine $(2 \times 50 \mathrm{~mL})$. The aqueous washings were extracted with EtOAc and the organic layers were combined and dried (anhydr. $\mathrm{MgSO}_{4}$ ). The solvent was evaporated in vacuo to afford 3-[(trityloxy)methyl]furan 5 as a yellow gum (4.98 g, 72\%) $\left[\delta_{\mathrm{H}} / \mathrm{ppm}\left(400 \mathrm{MHz} ; \mathrm{CDCl}_{3}\right) 4.06\left(2 \mathrm{H}, \mathrm{s}, \mathrm{OCH}_{2}\right), 6.43(1 \mathrm{H}, \mathrm{s}, 2-\mathrm{H}), 7.27-7.54(17 \mathrm{H}, \mathrm{m}, 4-\mathrm{H}, 5-\mathrm{H}\right.$ and trityl group); $\delta \mathrm{c} / \mathrm{ppm}\left(100 \mathrm{MHz} ; \mathrm{CDCl}_{3}\right) 58.4\left(\mathrm{OCH}_{2}\right), 86.9$ (C-2'), 109.9 (C-4), 123.1 (C-3), 127.0 (C-6'), 127.8 (C-4' and C-8'), 128.6 (C-5' and C-7'), 139.7 (C-3'), 143.0 (C-2) and 144.0 (C-5)], which was used without further purification.

The two procedures for the synthesis and characterisation of compounds $6 \mathrm{a}$ and $7 \mathrm{a}$ are illustrated below.

Method 1. To a stirred solution of 3-[(trityloxy)methyl]furan 5 (2.00 g, $5.88 \mathrm{mmol})$ in THF (20 mL) under $\mathrm{N}_{2}$ at ca. $-30{ }^{\circ} \mathrm{C}$, $n$-butyllithium (ca. $1.5 \mathrm{M}$ in hexane; $6.0 \mathrm{~mL}, 9 \mathrm{mmol}$ ) was slowly added dropwise via a septum, ensuring that the temperature did not exceed $-30^{\circ} \mathrm{C}$. The resulting mixture was stirred for 4 hours; DMF (1.38 $\mathrm{mL}$ ) was then added and the mixture stirred for a further 2 hours. The reaction mixture was allowed to warm to room temperature and stirred for an additional 2 hours before being quenched with water (15 $\mathrm{mL})$ and extracted with diethyl ether $(2 \times 50 \mathrm{~mL})$. The organic extracts were washed sequentially with $10 \%$ aq. $\mathrm{NaHCO}_{3}$ $(2 \times 50 \mathrm{~mL})$, brine $(2 \times 50 \mathrm{~mL})$ and dried (anhydr. $\left.\mathrm{MgSO}_{4}\right)$. The solvent was removed in vacuo to obtain the crude product as a yellow solid. A portion of the crude product was purified [normal-phase HPLC; elution with hexane-EtOAc (4:1)] to yield two products.

(i) 4-[(Trityloxy)methyl]furan-2-carbaldehyde (6a) as a pale yellow solid (12\%); $\delta_{\mathrm{H}} / \mathrm{ppm}\left(400 \mathrm{MHz} ; \mathrm{CDCl}_{3}\right) 4.45$ $\left(2 \mathrm{H}, \mathrm{s}, \mathrm{OCH}_{2}\right), 6.75(1 \mathrm{H}, \mathrm{s}, 5-\mathrm{H}), 7.26-7.49(15 \mathrm{H}, \mathrm{m}$, trityl group), $7.61(1 \mathrm{H}, \mathrm{s}, 3-\mathrm{H})$ and $9.73(1 \mathrm{H}, \mathrm{s}, \mathrm{CHO})$; $\delta_{\mathrm{C}} / \mathrm{ppm}\left(100 \mathrm{MHz} ; \mathrm{CDCl}_{3}\right) 57.8\left(\mathrm{OCH}_{2}\right), 87.3\left(\mathrm{C}-2^{\prime}\right), 120.5(\mathrm{C}-3), 126.4(\mathrm{C}-4), 127.2$ (C-6') 128 (C-4' and C-8'), 128.5 (C-5' and C-7'), 143.6 (C-3'), 145.2 (C-5), 153.1 (C-2) and 178.0 (C=0); and

(ii) the regioisomer, 3-[(Trityloxy)methyl]furan-2-carbaldehyde (7a) as a white solid (4\%); $\delta_{H} / \mathrm{ppm}(400 \mathrm{MHz}$; $\left.\mathrm{CDCl}_{3}\right) 4.14\left(2 \mathrm{H}, \mathrm{s}, \mathrm{OCH}_{2}\right), 7.31-7.69(17 \mathrm{H}, \mathrm{m}, 4-\mathrm{H}, 5-\mathrm{H}$ and trityl group) and $9.68(1 \mathrm{H}, \mathrm{s}, \mathrm{CHO}) ; \delta \mathrm{c} / \mathrm{ppm}(100$ $\left.\mathrm{MHz} ; \mathrm{CDCl}_{3}\right) 58.1\left(\mathrm{OCH}_{2}\right), 87.6$ (C-2'), 113.1 (C-4), 127.3 (C-6'), 128.0 (C-4' and C-8'), 128.6 (C-5' and C-7'), 135.4 (C-3), 143.5 (C-3'), 147.2 (C-5), 147.8 (C-2) and 178.5 (C=O).

Method 2. The Vilsmeier reagent was prepared by adding phosphorus oxychloride $(1.86 \mathrm{~mL}, 3.05 \mathrm{~g}, 20.0$ $\mathrm{mmol})$ dropwise to DMF $(20 \mathrm{~mL})$ under nitrogen over a period of $30 \mathrm{~min}$, maintaining the temperature below 5 ${ }^{\circ} \mathrm{C}$. The mixture was stirred for $30 \mathrm{~min}$, after which 3-[(trityloxy)methyl]furan 5 (2.00 g, $\left.5.88 \mathrm{mmol}\right)$ in DMF (5 $\mathrm{mL}$ ) was added. The reaction mixture was stirred for 3 hours at room temperature and then heated at $80{ }^{\circ} \mathrm{C}$ for 1 hour. After cooling, the mixture was poured into ice-water $(200 \mathrm{~mL})$ and the $\mathrm{pH}$ adjusted to $\mathrm{pH} 10$ with $0.1 \mathrm{M}$ aq. $\mathrm{NaOH}$. The solution was extracted with diethyl ether $(4 \times 50 \mathrm{~mL})$, and the organic extracts were combined, washed with water and brine and the dried (anhydr. $\mathrm{MgSO}_{4}$ ). The solvent was removed in vacuo to afford the crude product, which was recrystallised from $\mathrm{MeOH}$ to yield 4-[(trityloxy)methyl]furan-2carbaldehyde $6 \mathrm{a}$ as pale-yellow crystals (1.39 g, 64\%).

The general procedure for the synthesis and characterisation of compounds $\mathbf{6 b}$ and $\mathbf{6 c}$ is illustrated by the following example. Acetic anhydride $(0.27 \mathrm{~mL}, 2.9 \mathrm{mmol})$ was added dropwise to a solution of $\mathrm{SnCl}_{4}(0.12 \mathrm{~mL}$, $0.27 \mathrm{~g}, 1.0 \mathrm{mmol})$ in $\mathrm{DCM}(10 \mathrm{~mL})$ under $\mathrm{N}_{2}$ at $0{ }^{\circ} \mathrm{C}$ and the mixture was stirred for $15 \mathrm{~min}$. 3- 
[(Trityloxy)methyl]furan (5) $(1.00 \mathrm{~g}, 2.94 \mathrm{mmol})$ in $\mathrm{DCM}(10 \mathrm{~mL})$ was added and the reaction mixture was stirred at $0{ }^{\circ} \mathrm{C}$ for 1 hour. The reaction mixture was then warmed to $40{ }^{\circ} \mathrm{C}$ and stirred for 4 hours. After completion, the mixture was treated with saturated aq. $\mathrm{NaHCO}_{3}(50 \mathrm{~mL})$ and extracted with diethyl ether $(2 \mathrm{x}$ $50 \mathrm{~mL}$ ). The organic extracts were combined, dried (anhydr. $\mathrm{MgSO}_{4}$ ) and filtered. The solvent was removed under reduced pressure and a portion of the residue was purified [normal-phase HPLC; elution with hexaneEtOAc (3:1)] to yield two products.

(i) 2-Acetyl-4-[(trityloxy)methyl]furan (6b). Yellow oil (64\%); v/cm-1 1675 (C=O); $\delta_{H} / p p m\left(400 ~ \mathrm{MHz}^{-} \mathrm{CDCl}_{3}\right)$ $2.57\left(3 \mathrm{H}, \mathrm{s}, \mathrm{CH}_{3} \mathrm{CO}\right), 4.42\left(2 \mathrm{H}, \mathrm{s}, \mathrm{OCH}_{2}\right)$ and $7.14-7.34(17 \mathrm{H}, \mathrm{m}, 3-\mathrm{H}, 5-\mathrm{H}$ and trityl group); $\delta \mathrm{c} / \mathrm{ppm}(100 \mathrm{MHz} ;$ $\left.\mathrm{CDCl}_{3}\right) 24.2\left(\mathrm{CH}_{3}\right), 57.3\left(\mathrm{OCH}_{2}\right), 87.6\left(\mathrm{C}-2^{\prime}\right), 120.4(\mathrm{C}-3), 126.4$ (C-4), 127.4 (C-6') 127.9 (C-4' and C-8'), 128.4 (C5' and C-7'), 143.5 (C-3'), 145.3 (C-5), 153.5 (C-2) and 181.3 (C=O); (Found: C, 81.58; $\mathrm{H}, 5.76 \% . \mathrm{C}_{26} \mathrm{H}_{22} \mathrm{O}_{3}$ requires $\mathrm{C}, 81.65 ; \mathrm{H}, 5.80 \%)$; and

(ii) the regioisomer, 2-Acetyl-3-[(trityloxy)methyl]furan (7b). Yellow oil (2\%); v/cm ${ }^{-1} 1682$ (C=O); $\delta_{H} / p p m(400$ $\left.\mathrm{MHz} ; \mathrm{CDCl}_{3}\right) 2.59\left(3 \mathrm{H}, \mathrm{s}, \mathrm{CH}_{3} \mathrm{CO}\right), 4.45\left(2 \mathrm{H}, \mathrm{s}, \mathrm{OCH}_{2}\right)$ and $7.12-7.28(17 \mathrm{H}, \mathrm{m}, 4-\mathrm{H}, 5-\mathrm{H}$ and trityl group); $\delta \mathrm{c} / \mathrm{ppm}$ $\left(100 \mathrm{MHz} ; \mathrm{CDCl}_{3}\right) 24.8\left(\mathrm{CH}_{3}\right), 56.8\left(\mathrm{OCH}_{2}\right), 87.3\left(\mathrm{C}-2^{\prime}\right), 112.8(\mathrm{C}-4), 126.7\left(\mathrm{C}-6^{\prime}\right), 128.1$ (C-4' and C-8'), $128.8\left(\mathrm{C}-5^{\prime}\right.$

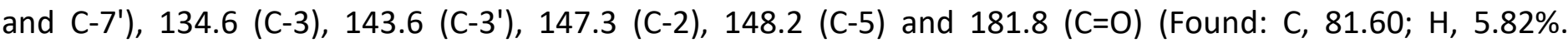
$\mathrm{C}_{26} \mathrm{H}_{22} \mathrm{O}_{3}$ requires $\mathrm{C}, 81.65 ; \mathrm{H}, 5.80 \%$ ).

2-(3,3-Dimethylbutanoyl)-4-[(trityloxy)methyl]furan (6c). Yellow oil (56\%); v/cm 1685 (C=O); $\delta_{H} / p p m(400$ $\left.\mathrm{MHz} ; \mathrm{CDCl}_{3}\right) 1.19\left(9 \mathrm{H}, \mathrm{s}, 3 \times \mathrm{CH}_{3}\right), 2.58\left(2 \mathrm{H}, \mathrm{s}, \mathrm{CH}_{2} \mathrm{CO}\right), 4.47\left(2 \mathrm{H}, \mathrm{s}, \mathrm{OCH}_{2}\right)$ and $7.19-7.31(17 \mathrm{H}, \mathrm{m}, 3-\mathrm{H}, 5-\mathrm{H}$ and trityl group); $\delta_{\mathrm{c}} / \mathrm{ppm}\left(100 \mathrm{MHz} ; \mathrm{CDCl}_{3}\right) 29.1\left(3 \times \mathrm{CH}_{3}\right), 30.2\left(\mathrm{C}-3^{\prime \prime}\right), 47.4\left(\mathrm{C}-2^{\prime \prime}\right), 57.9\left(\mathrm{OCH}_{2}\right), 87.4\left(\mathrm{C}-2^{\prime}\right), 120.6$ (C-3), 126.4 (C-4), 127.3 (C-6') 128.0 (C-4' and C-8'), 128.6 (C-5' and C-7'), 143.7 (C-3'), 145.3 (C-5), 153.2 (C-2) and $187.0(\mathrm{C}=\mathrm{O})$; (Found: $\mathrm{C}, 82.30 ; \mathrm{H}, 6.78 \% . \mathrm{C}_{30} \mathrm{H}_{30} \mathrm{O}_{3}$ requires $\mathrm{C}, 82.16 ; \mathrm{H}, 6.89 \%$ ).

2-(3,3-Dimethylbutanoyl)-3-[(trityloxy)methyl]furan (7c). Yellow oil (3\%); (Found: $\mathrm{C}, 82.35 ; \mathrm{H}, 6.83 \% . \mathrm{C}_{30} \mathrm{H}_{30} \mathrm{O}_{3}$ requires $\mathrm{C}, 82.16 ; \mathrm{H}, 6.89 \%) ; \mathrm{v} / \mathrm{cm}^{-1} 1691(\mathrm{C}=\mathrm{O}) ; \delta_{\mathrm{H}} / \mathrm{ppm}\left(400 \mathrm{MHz} ; \mathrm{CDCl}_{3}\right) 1.21\left(9 \mathrm{H}, \mathrm{s}, 3 \times \mathrm{CH}_{3}\right), 2.56(2 \mathrm{H}, \mathrm{s}$, $\left.\mathrm{CH}_{2} \mathrm{CO}\right), 4.52\left(2 \mathrm{H}, \mathrm{s}, \mathrm{OCH}_{2}\right)$ and $7.14-7.21\left(17 \mathrm{H}, \mathrm{m}, 4-\mathrm{H}, 5-\mathrm{H}\right.$ and trityl group); $\delta_{c} / p p m\left(100 \mathrm{MHz} ; \mathrm{CDCl}_{3}\right) 29.5$ (3 $\mathrm{CCH}_{3}$ ), $31.3\left(\mathrm{C}-3^{\prime \prime}\right), 46.8\left(\mathrm{C}-2^{\prime \prime}\right), 58.2\left(\mathrm{OCH}_{2}\right), 87.3$ (C-2'), $113.2(\mathrm{C}-4), 126.6\left(\mathrm{C}^{\prime} \mathrm{6}^{\prime}\right), 127.8$ (C-4' and C-8'), 128.9 (C-5' and C-7'), 132.8 (C-3), 143.8 (C-3'), 145.7 (C-5), 146.4 (C-2) and 186.4 (C=O); (Found: C, 82.35; H, 6.83\%. $\mathrm{C}_{30} \mathrm{H}_{30} \mathrm{O}_{3}$ requires $\left.\mathrm{C}, 82.16 ; \mathrm{H}, 6.89 \%\right)$.

General procedure for the synthesis of compounds $8 \mathrm{a}-\mathrm{c}$, which were used witout further purification, is illustrated by the following example. (Compounds $\mathbf{8 a , b}$ are known. ${ }^{48}$ ) A suspension of 2-(3,3dimethylbutanoyl)-4-[(trityloxy)methyl]furan (6c) $(0.25 \mathrm{~g}, 0.57 \mathrm{mmol})$ in $\mathrm{HCOOH}-\mathrm{THF}-\mathrm{H}_{2} \mathrm{O}(1: 1: 0.1 ; 5 \mathrm{~mL})$ was heated at $50{ }^{\circ} \mathrm{C}$ for 2 hours. The solvent was removed in vacuo, [co-evaporated with hexane $(2 \times 10 \mathrm{~mL})$ ] to yield 2-(3,3-dimethylbutanoyl)-4-(hydroxymethyl)furan (8c) as a colourless oil $\left[\delta_{\mathrm{H}} / \mathrm{ppm}\left(400 \mathrm{MHz} \mathrm{CDCl}_{3}\right) 1.19\right.$ $\left(9 \mathrm{H}, \mathrm{s}, 3 \times \mathrm{CH}_{3}\right), 2.12(1 \mathrm{H}, \mathrm{s}, \mathrm{OH}), 2.54\left(2 \mathrm{H}, \mathrm{s}, \mathrm{CH}_{2} \mathrm{CO}\right), 4.52\left(2 \mathrm{H}, \mathrm{s}, \mathrm{OCH}_{2}\right), 6.41(1 \mathrm{H}, \mathrm{s}, 5-\mathrm{H})$ and $7.39(1 \mathrm{H}, \mathrm{s}, 3-\mathrm{H})$; $\delta \mathrm{c} / \mathrm{ppm}\left(100 \mathrm{MHz} ; \mathrm{CDCl}_{3}\right) 28.6\left(3 \times \mathrm{CH}_{3}\right), 32.6\left(\mathrm{C}-3^{\prime}\right), 36.7\left(\mathrm{C}-2^{\prime}\right), 58.6\left(\mathrm{CH}_{2} \mathrm{OH}\right), 120.2(\mathrm{C}-3), 123.8(\mathrm{C}-4), 145.3$ (C-5), 153.2 (C-2) and 184.7 ( $C=0)$ ] which was used without further purification.

General procedure for the synthesis of compounds $9 a-c$ is illustrated by the following example. Diethyl chlorophosphate $(0.52 \mathrm{~g}, 3.0 \mathrm{mmol})$ was added slowly to a stirred solution of 4-(hydroxymethyl)furan-2carbaldehyde $(8 \mathrm{a})(0.20 \mathrm{~g}, 1.6 \mathrm{mmol})$ in pyridine $(10 \mathrm{~mL})$ at $0{ }^{\circ} \mathrm{C}$. The reaction mixture was allowed to reach room temperature and then stirred for 24 hours. The solvent was removed in vacuo and the residue was dissolved in DCM $(25 \mathrm{~mL})$. The organic phase was washed with satd. aq. $\mathrm{NaHCO}_{3}(2 \times 50 \mathrm{~mL})$, water $(2 \times 50 \mathrm{~mL})$ and brine $(2 \times 50 \mathrm{~mL})$, and dried (anhydr. $\left.\mathrm{MgSO}_{4}\right)$. The solvent was evaporated in vacuo and the residue chromatographed [preparative layer chromatography; elution with hexane-EtOAc (4:1)] to yield diethyl (2formylfuran-4-yl)methyl phosphate (9a) as a clear oil (0.14 g, 34\%); v/cm 1677 (C=O) and $1227(\mathrm{P}=0)$; $\delta_{\mathrm{H}} / \mathrm{ppm}\left(400 \mathrm{MHz} ; \mathrm{CDCl}_{3}\right) 1.29\left(6 \mathrm{H}, \mathrm{m}, 2 \times \mathrm{CH}_{3}\right), 4.10\left(4 \mathrm{H}, \mathrm{m}, 2 \times \mathrm{CH}_{2} \mathrm{CH}_{3}\right), 4.87\left(2 \mathrm{H}, \mathrm{d}, J 2.2 \mathrm{~Hz}, \mathrm{OCH}_{2}\right), 6.45(1 \mathrm{H}$, 
s, 5-H), $7.39(1 \mathrm{H}, \mathrm{s}, 3-\mathrm{H})$ and $10.12(1 \mathrm{H}, \mathrm{s}, \mathrm{CHO}) ; \delta \mathrm{c} / \mathrm{ppm}\left(100 \mathrm{MHz} ; \mathrm{CDCl}_{3}\right) 16.3\left(\mathrm{~d}, \mathrm{~J}_{\mathrm{F}-\mathrm{c}} 6.1 \mathrm{~Hz}, 2 \times \mathrm{CH}_{3}\right), 60.8(\mathrm{~d}$, $J_{\mathrm{P}-\mathrm{C}} 6.4 \mathrm{~Hz}, \mathrm{OCH}_{2}$ ), 61.4 (d, $J_{\mathrm{P}-\mathrm{C}} 6.6 \mathrm{~Hz}, 2 \times \mathrm{CH}_{2} \mathrm{CH}_{3}$ ), 120.3 (C-3), 125.6 (C-4), 145.3 (C-5), 153.2 (C-2) and 181.7 (C=O); (Found: $\mathrm{C}, 45.90 ; \mathrm{H}, 5.84 \% . \mathrm{C}_{10} \mathrm{H}_{15} \mathrm{O}_{6} \mathrm{P}$ requires $\mathrm{C}, 45.81 ; \mathrm{H}, 5.77 \%$ ).

(2-Acetylfuran-4-yl)methyl diethyl phosphate (9b). Yellow oil (0.15 g, 38\%); v/cm $\mathrm{cm}^{-1} 1680$ (C=O) and 1223 $(\mathrm{P}=\mathrm{O}) ; \delta_{\mathrm{H}} / \mathrm{ppm}\left(400 \mathrm{MHz} ; \mathrm{CDCl}_{3}\right) 1.30\left(6 \mathrm{H}, \mathrm{t}, J 6.8 \mathrm{~Hz}, 2 \times \mathrm{CH}_{2} \mathrm{CH}_{3}\right), 2.54\left(3 \mathrm{H}, \mathrm{s}, \mathrm{CH}_{3} \mathrm{CO}\right), 4.07(4 \mathrm{H}, \mathrm{m}, 2 \mathrm{x}$ $\left.\mathrm{CH}_{2} \mathrm{CH}_{3}\right), 5.05\left(2 \mathrm{H}, \mathrm{d}, J 1.6 \mathrm{~Hz}, \mathrm{OCH}_{2}\right), 7.11(1 \mathrm{H}, \mathrm{s}, 5-\mathrm{H})$ and $7.13(2 \mathrm{H}, \mathrm{s}, 3-\mathrm{H}) ; \delta \mathrm{c} / \mathrm{ppm}\left(100 \mathrm{MHz} ; \mathrm{CDCl}_{3}\right) 16.3(\mathrm{~d}$, $\left.J_{\mathrm{P}-\mathrm{C}} 6.0 \mathrm{~Hz}, 2 \times \mathrm{CH}_{3}\right), 24.6\left(\mathrm{CH}_{3} \mathrm{CO}\right), 61.5\left(\mathrm{~d}, \mathrm{~J}_{\mathrm{P}-\mathrm{C}} 6.5 \mathrm{~Hz}, \mathrm{OCH}_{2}\right.$ and $\left.2 \times \mathrm{CH}_{2} \mathrm{CH}_{3}\right), 120.8$ (C-3), 122.9 (C-4), 145.7 (C5), 150.1 (C-2) and 182.6 ( $C=O)$; (Found: $\mathrm{C}, 48.01 ; \mathrm{H}, 6.15 \% . \mathrm{C}_{11} \mathrm{H}_{17} \mathrm{O}_{6} \mathrm{P}$ requires $\mathrm{C}, 47.83 ; \mathrm{H}, 6.20 \%$ ).

Diethyl [2-(3,3-dimethylbutanoyl)furan-4-yl]methyl phosphate (9c). Yellow oil (0.14 g, 41\%); v/cm 1681 $(\mathrm{C}=0)$ and $1232(\mathrm{P}=\mathrm{O}) ; \delta_{\mathrm{H}} / \mathrm{ppm}\left(400 \mathrm{MHz} ; \mathrm{CDCl}_{3}\right) 1.21\left(9 \mathrm{H}, \mathrm{s}, 3 \times \mathrm{CH}_{3}\right), 1.31\left(6 \mathrm{H}, \mathrm{t}, \mathrm{J} 6.8 \mathrm{~Hz}, 2 \times \mathrm{CH}_{2} \mathrm{CH}_{3}\right), 2.56$ $\left(2 \mathrm{H}, \mathrm{s}, \mathrm{CH}_{2} \mathrm{CO}\right), 4.08\left(4 \mathrm{H}, \mathrm{m}, 2 \times \mathrm{CH}_{2} \mathrm{CH}_{3}\right), 5.09\left(2 \mathrm{H}, \mathrm{d}, \mathrm{J} 1.6 \mathrm{~Hz}, \mathrm{OCH}_{2}\right), 6.47(1 \mathrm{H}, \mathrm{s}, 5-\mathrm{H})$ and $7.12(1 \mathrm{H}, \mathrm{s}, 3-\mathrm{H})$; $\delta \mathrm{c} / \mathrm{ppm}\left(100 \mathrm{MHz} ; \mathrm{CDCl}_{3}\right) 16.3\left(\mathrm{~d}, \mathrm{~J}_{\mathrm{P}-\mathrm{C}} 6.1 \mathrm{~Hz}, 2 \times \mathrm{CH}_{2} \mathrm{CH}_{3}\right), 29.2\left(3 \times \mathrm{CH}_{3}\right), 32.3\left(\mathrm{C}-3^{\prime}\right), 36.8\left(\mathrm{C}-2^{\prime}\right), 62.3\left(\mathrm{~d}, J_{\mathrm{P}-\mathrm{C}}\right.$ $6.5 \mathrm{~Hz}, \mathrm{OCH}_{2}$ and $2 \times \mathrm{CH}_{2} \mathrm{CH}_{3}$ ), 120.5 (C-3), 124.2 (C-4), 145.7 (C-5), 153.4 (C-2) and 185.3 (C=O); (Found: C, $54.30 ; \mathrm{H}, 7.60 \%$. $\mathrm{C}_{15} \mathrm{H}_{25} \mathrm{O}_{6} \mathrm{P}$ requires $\left.\mathrm{C}, 54.21 ; \mathrm{H}, 7.58 \%\right)$.

General procedure for the synthesis of compounds 10a-c is illustrated by the following example. A solution of 4-[(trityloxy)methyl]furan-2-carbaldehyde (6a) $(0.30 \mathrm{~g}, 0.82 \mathrm{mmol})$ and $\mathrm{H}_{3} \mathrm{PO}_{4} / \mathrm{THF}(1: 1 \mathrm{v} / \mathrm{v} ; 2.0 \mathrm{~mL})$ was stirred at room temperature for $c a$. 2 days. The solvent was removed under reduced pressure and the residue dissolved in EtOAc $(25 \mathrm{~mL})$. The organic phase was washed with $10 \%$ aq. $\mathrm{NaHCO}_{3}(2 \times 50 \mathrm{~mL})$, and the aqueous layers were collected and acidified $(\mathrm{pH} 2.0)$ with $0.1 \mathrm{M}-\mathrm{HCl}$. The aqueous phase was extracted with EtOAc $(3 \mathrm{x}$ $25 \mathrm{~mL}$ ) and the combined organic solutions were dried (anhydr. $\mathrm{MgSO}_{4}$ ). The solvent was evaporated in vacuo and the residue chromatographed [preparative layer chromatography; elution with hexane-EtOAc-MeOH $(1: 1: 1)]$ to yield (2-formylfuran-4-yl)methyl dihydrogen phosphate (10a). Yellow oil (71\%); $\mathrm{v} / \mathrm{cm}^{-1} 1673$ (C=O) and $1234(\mathrm{P}=\mathrm{O}) ; \delta_{\mathrm{H}} / \mathrm{ppm}\left(400 \mathrm{MHz} ; \mathrm{D}_{2} \mathrm{O}\right) 5.11\left(2 \mathrm{H}, \mathrm{d}, J 1.6 \mathrm{~Hz}, \mathrm{OCH}_{2}\right), 7.10(1 \mathrm{H}, \mathrm{s}, 5-\mathrm{H}), 7.40(1 \mathrm{H}, \mathrm{s}, 3-\mathrm{H})$ and $9.74(1 \mathrm{H}, \mathrm{s}, \mathrm{CHO}) ; \delta \mathrm{c} / \mathrm{ppm}\left(100 \mathrm{MHz} ; \mathrm{D}_{2} \mathrm{O}\right) 61.9$ (d, JP-C $6.4 \mathrm{~Hz}, 2 \times \mathrm{OCH}_{2}$ ), 120.9 (C-3), 123.0 (C-4), 145.8 (C-5), 150.2 (C-2) and 180.0 ( $\mathrm{C}=\mathrm{O}$ ); (Found: $\mathrm{C}, 35.01 ; \mathrm{H}, 3.49 \% . \mathrm{C}_{6} \mathrm{H}_{7} \mathrm{O}_{6} \mathrm{P}$ requires $\mathrm{C}, 34.97 ; \mathrm{H}, 3.42 \%$ ).

(2-Acetylfuran-4-yl)methyl dihydrogen phosphate (10b). Colourless oil (61\%); v/cm 1687 (C=O) and 1241 $(\mathrm{P}=\mathrm{O}) ; \delta_{\mathrm{H}} / \mathrm{ppm}\left(400 \mathrm{MHz} ; \mathrm{D}_{2} \mathrm{O}\right) 2.61\left(3 \mathrm{H}, \mathrm{s}, \mathrm{CH}_{3} \mathrm{CO}\right), 5.07\left(2 \mathrm{H}, \mathrm{d}, \mathrm{J} 2.3 \mathrm{~Hz}, \mathrm{OCH}_{2}\right), 7.12(1 \mathrm{H}, \mathrm{s}, 5-\mathrm{H})$ and $7.35(1 \mathrm{H}$, s, 3-H); $\delta_{c} / p p m\left(100 \mathrm{MHz} ; \mathrm{D}_{2} \mathrm{O}\right) 24.3\left(\mathrm{CH}_{3}\right), 62.3\left(\mathrm{~d}, \mathrm{~J}_{\mathrm{P}-\mathrm{C}} 6.5 \mathrm{~Hz}, \mathrm{OCH}_{2}\right.$ ), 120.7 (C-3), 122.9 (C-4), 145.5 (C-5), 153.2 (C-2) and $182.3\left(\mathrm{C}=\mathrm{O}\right.$ ); (Found: $\mathrm{C}, 38.27 ; \mathrm{H}, 4.09 \%$. $\mathrm{C}_{7} \mathrm{H}_{9} \mathrm{O}_{6} \mathrm{P}$ requires $\mathrm{C}, 38.20 ; \mathrm{H}, 4.12 \%$ ).

[2-(3,3-Dimethylbutanoyl)furan-4-yl]methyl dihydrogen phosphate (10c). Colourless oil (58\%); (Found: $\mathrm{C}$, 47.91; $\mathrm{H}, 6.11 \%$. $\mathrm{C}_{11} \mathrm{H}_{17} \mathrm{O}_{6} \mathrm{P}$ requires $\left.\mathrm{C}, 47.83 ; \mathrm{H}, 6.20 \%\right) ; \mathrm{v} / \mathrm{cm}^{-1} 3307(\mathrm{OH}), 1687(\mathrm{C}=\mathrm{O})$ and $1231(\mathrm{P}=\mathrm{O})$; $\delta_{H} / p p m\left(400 \mathrm{MHz} ; \mathrm{D}_{2} \mathrm{O}\right) 1.21\left(9 \mathrm{H}, \mathrm{s}, 3 \times \mathrm{CH}_{3}\right), 2.55\left(2 \mathrm{H}, \mathrm{s}, \mathrm{CH}_{2} \mathrm{CO}\right), 5.02\left(2 \mathrm{H}, \mathrm{d}, J 2.4 \mathrm{~Hz}, \mathrm{OCH}_{2}\right), 7.15(1 \mathrm{H}, \mathrm{s}, 5-\mathrm{H})$ and $7.39(1 \mathrm{H}, \mathrm{s}, 3-\mathrm{H}) ; \delta \mathrm{c} / \mathrm{ppm}\left(100 \mathrm{MHz} ; \mathrm{D}_{2} \mathrm{O}\right) 29.3\left(3 \times \mathrm{CH}_{3}\right), 32.2\left(\mathrm{C}-3{ }^{\prime}\right), 36.8\left(\mathrm{C}-2{ }^{\prime}\right), 62.2\left(\mathrm{~d}, \mathrm{~J}_{\mathrm{P}-\mathrm{C}} 6.5 \mathrm{~Hz}, \mathrm{OCH}_{2}\right)$, 120.4 (C-3), 123.7 (C-4), 145.5 (C-5), 152.8 (C-2) and 185.6 (C=O). (Found: C, 47.91; $\mathrm{H}, 6.11 \% . \mathrm{C}_{11} \mathrm{H}_{17} \mathrm{O}_{6} \mathrm{P}$ requires $\mathrm{C}, 47.83 ; \mathrm{H}, 6.20 \%)$.

General procedure for the synthesis of compounds 11a-c is illustrated by the following example. Diethyl (2formylfuran-4-yl)methyl phosphate (9a) $(0.11 \mathrm{~g}, 0.42 \mathrm{mmol})$, hydroxylamine hydrochloride $(0.10 \mathrm{~g}, 1.4 \mathrm{mmol})$ and sodium acetate $(0.020 \mathrm{~g}, 0.24 \mathrm{mmol})$ were dissolved in EtOH $(8 \mathrm{~mL})$ and the mixture was refluxed for 1 hour. After completion of the reaction, the solvent was removed under reduced pressure and the residue was dissolved in diethyl ether $(20 \mathrm{~mL})$. The organic layer was washed sequentially with water $(20 \mathrm{~mL})$ and brine $(20$ $\mathrm{mL}$ ), and dried (anhydr. $\mathrm{Na}_{2} \mathrm{SO}_{4}$ ). The solvent was removed in vacuo and the residue chromatographed [preparative layer chromatography; elution with hexane-EtOAc (4:1)] to yield diethyl $\{\mathbf{2}-[(\mathbf{N}$ hydroxyimino)methyl]furan-4-yl\}methyl phosphate (11a). Colourless oil (97 mg, 83\%); (Found: C, 43.47; H, 5.69; $\mathrm{N}, 5.11 \% . \mathrm{C}_{10} \mathrm{H}_{16} \mathrm{NO}_{6} \mathrm{P}$ requires $\left.\mathrm{C}, 43.33 ; \mathrm{H}, 5.82 ; \mathrm{N}, 5.05 \%\right) ; \mathrm{v} / \mathrm{cm}^{-1} 3271(\mathrm{OH}), 1651(\mathrm{C}=\mathrm{N})$ and 1218 
$(\mathrm{P}=\mathrm{O}) ; \delta_{\mathrm{H}} / \mathrm{ppm}\left(400 \mathrm{MHz} ; \mathrm{CDCl}_{3}\right) 1.28\left(6 \mathrm{H}, \mathrm{m}, 2 \times \mathrm{CH}_{3}\right), 4.08\left(4 \mathrm{H}, \mathrm{m}, 2 \times \mathrm{CH}_{2} \mathrm{CH}_{3}\right), 5.05\left(2 \mathrm{H}, \mathrm{d}, \mathrm{J} 2.0 \mathrm{~Hz}, \mathrm{OCH}_{2}\right)$, $6.44(1 \mathrm{H}, \mathrm{s}, 5-\mathrm{H}), 7.41(1 \mathrm{H}, \mathrm{s}, 3-\mathrm{H}), 8.17(1 \mathrm{H}, \mathrm{s}, \mathrm{OH})$ and $9.89\left(1 \mathrm{H}, \mathrm{s}\right.$, aldehydic proton); $\delta_{\mathrm{c}} / \mathrm{ppm}(100 \mathrm{MHz} ;$ $\left.\mathrm{CDCl}_{3}\right) 16.2\left(\mathrm{~d}, J_{\mathrm{P}-\mathrm{C}} 6.5 \mathrm{~Hz}, 2 \times \mathrm{CH}_{3}\right), 59.8\left(\mathrm{~d}, J_{\mathrm{P}-\mathrm{C}} 6.4 \mathrm{~Hz}, \mathrm{OCH}_{2}\right), 61.3\left(\mathrm{~d}, J_{\mathrm{F}-\mathrm{C}} 6.5 \mathrm{~Hz}, 2 \times \mathrm{CH}_{2} \mathrm{CH}_{3}\right), 110.7$ (C-3), 125.7 (C-4), 145.1 (C-5), 149. 6 (C=N) and 153.7 (C-2).

Diethyl \{2-[1-( $N$-hydroxyimino)ethyl]furan-4-yl\}methyl phosphate (11b). Colourless oil (91 mg, 86\%); $v / \mathrm{cm}^{-1}$ $3243(\mathrm{OH}), 1672(\mathrm{C}=\mathrm{N})$ and $1225(\mathrm{P}=\mathrm{O}) ; \delta_{\mathrm{H}} / \mathrm{ppm}\left(400 \mathrm{MHz} ; \mathrm{CDCl}_{3}\right) 1.31\left(6 \mathrm{H}, \mathrm{t}, J 7.2 \mathrm{~Hz}, 2 \times \mathrm{CH}_{3}\right), 2.53(3 \mathrm{H}, \mathrm{s}$, $\left.\mathrm{CH}_{3} \mathrm{C}=\mathrm{N}\right), 4.09\left(4 \mathrm{H}, \mathrm{m}, 2 \times \mathrm{CH}_{2} \mathrm{CH}_{3}\right), 5.02\left(2 \mathrm{H}, \mathrm{d}, \mathrm{J} 2.0 \mathrm{~Hz}, \mathrm{OCH}_{2}\right), 5.87(1 \mathrm{H}, \mathrm{s}, \mathrm{OH}), 6.48(1 \mathrm{H}, \mathrm{s}, 5-\mathrm{H})$ and $7.11(1 \mathrm{H}$, s, 3-H); $\delta \mathrm{c} / \mathrm{ppm}\left(100 \mathrm{MHz} ; \mathrm{CDCl}_{3}\right) 13.0\left(\mathrm{CH}_{3} \mathrm{C}=\mathrm{N}\right) 16.3\left(\mathrm{~d}, \mathrm{~J}_{\mathrm{P}-\mathrm{C}} 6.0 \mathrm{~Hz}, 2 \times \mathrm{CH}_{3}\right), 61.7\left(\mathrm{~d}, \mathrm{~J}_{\mathrm{P}-\mathrm{C}} 6.4 \mathrm{~Hz}, \mathrm{OCH}_{2}\right.$ and $2 \mathrm{x}$ $\mathrm{CH}_{2} \mathrm{CH}_{3}$ ), 109.8 (C-3), 127.2 (C-4), 143.7 (C-5), 148.5 (C=N) and 151.3 (C-2). (Found: C, 45.27; H, 6.14; N, 4.88\%. $\mathrm{C}_{11} \mathrm{H}_{18} \mathrm{NO}_{6} \mathrm{P}$ requires $\left.\mathrm{C}, 45.36 ; \mathrm{H}, 6.23 ; \mathrm{N}, 4.81 \%\right)$.

Diethyl \{2-[1-(N-hydroxyimino)-3,3-dimethylbutyl]furan-4-yl\}methyl phosphate (11c). Colourless oil (92 mg, 88\%); v/cm $3281(\mathrm{OH}) 1663(\mathrm{C}=\mathrm{N})$ and $1218(\mathrm{P}=\mathrm{O}) ; \delta_{\mathrm{H}} / \mathrm{ppm}\left(400 \mathrm{MHz} ; \mathrm{CDCl}_{3}\right) 1.15\left(9 \mathrm{H}, \mathrm{s}, 3 \times \mathrm{CH}_{3}\right), 1.26(6 \mathrm{H}, \mathrm{t}$, J $\left.6.8 \mathrm{~Hz}, 2 \times \mathrm{CH}_{2} \mathrm{CH}_{3}\right), 2.55\left(2 \mathrm{H}, \mathrm{CH}_{2} \mathrm{C}=\mathrm{N}\right), 4.03\left(4 \mathrm{H}, \mathrm{m}, 2 \times \mathrm{CH}_{2} \mathrm{CH}_{3}\right), 4.98\left(2 \mathrm{H}, \mathrm{d}, J 1.6 \mathrm{~Hz}, \mathrm{OCH}_{2}\right), 5.67(1 \mathrm{H}, \mathrm{s}, \mathrm{OH})$, $6.50(1 \mathrm{H}, \mathrm{s}, 5-\mathrm{H})$ and $7.12(1 \mathrm{H}, \mathrm{s}, 3-\mathrm{H}) ; \delta_{\mathrm{C}} / \mathrm{ppm}\left(100 \mathrm{MHz} ; \mathrm{CDCl}_{3}\right) 16.2\left(\mathrm{~d}, \mathrm{~J}_{\mathrm{p}-\mathrm{C}} 6.0 \mathrm{~Hz}, 2 \times \mathrm{CH}_{2} \mathrm{CH}_{3}\right), 28.6\left(3 \times \mathrm{CH}_{3}\right)$, 32.4 (C-3'), 36.6 (C-2'), $62.0\left(\mathrm{OCH}_{2}\right), 62.1$ (d, JP-C $\left.6.7 \mathrm{~Hz}, 2 \times \mathrm{CH}_{2} \mathrm{CH}_{3}\right), 110.3$ (C-3), 127.6 (C-4), 143.3 (C-5), 149.8 $\left(\mathrm{C}=\mathrm{N}\right.$ ) and 153.4 (C-2). (Found: $\mathrm{C}, 51.79 ; \mathrm{H}, 7.49 ; \mathrm{N}, 3.97 \% . \mathrm{C}_{15} \mathrm{H}_{26} \mathrm{NO}_{6} \mathrm{P}$ requires $\left.\mathrm{C}, 51.87 ; \mathrm{H}, 7.54 ; \mathrm{N}, 4.03 \%\right)$.

General procedure for the synthesis of compounds 3a-c is illustrated by the following example. (2Formylfuran-4-yl)methyl dihydrogen phosphate (10a) $(0.10 \mathrm{~g}, 0.49 \mathrm{mmol})$, hydroxylamine hydrochloride $(0.10$ $\mathrm{g}, 1.4 \mathrm{mmol})$ and sodium acetate $(0.020 \mathrm{~g}, 0.24 \mathrm{mmol})$ were dissolved in $\mathrm{EtOH}(8 \mathrm{~mL})$ and the mixture was refluxed for 1 hour. After completion of the reaction, the solvent was removed under reduced pressure and the residue was dissolved in diethyl ether $(20 \mathrm{~mL})$. The organic solution was washed sequentially with water $(20 \mathrm{~mL})$ and brine $(20 \mathrm{~mL})$, and dried (anhydr. $\left.\mathrm{Na}_{2} \mathrm{SO}_{4}\right)$. The solvent was removed in vacuo and the residue chromatographed [preparative layer chromatography; elution with hexane-EtOAc-MeOH (1:1:1)] to yield \{2[(N-hydroxyimino)methyl]furan-4-yl\}methyl dihydrogen phosphate (3a). Colourless oil (88 mg, 82\%); (Found: $\mathrm{C}, 32.71 ; \mathrm{H}, 3.72 ; \mathrm{N}, 6.30 \%$. $\mathrm{C}_{6} \mathrm{H}_{8} \mathrm{NO}_{6} \mathrm{P}$ requires $\left.\mathrm{C}, 32.59 ; \mathrm{H}, 3.65 ; \mathrm{N}, 6.33 \%\right) ; \mathrm{v} / \mathrm{cm}^{-1} 3245(\mathrm{OH}), 1657(\mathrm{CH}=\mathrm{N})$ and $1232(\mathrm{P}=\mathrm{O}) ; \delta_{\mathrm{H}} / \mathrm{ppm}(400 \mathrm{MHz}$; DMSO-d $) 3.57(2 \mathrm{H}, \mathrm{s}, 2 \times \mathrm{OH}), 5.11\left(2 \mathrm{H}, \mathrm{d}, J 2.0 \mathrm{~Hz}, \mathrm{OCH}_{2}\right), 5.89(1 \mathrm{H}, \mathrm{s}$, $\mathrm{CH}=\mathrm{N}), 7.10(1 \mathrm{H}, \mathrm{s}, 5-\mathrm{H}), 7.37(1 \mathrm{H}, \mathrm{s}, 3-\mathrm{H})$ and $9.41(1 \mathrm{H}, \mathrm{s}, \mathrm{NOH}) ; \delta_{\mathrm{c}} / \mathrm{ppm}(100 \mathrm{MHz} \text {; DMSO-d })_{6} 62.2\left(\mathrm{~d}, J_{\mathrm{P}-\mathrm{C}}=5.9\right.$ $\mathrm{Hz}, \mathrm{OCH}_{2}$ ), 110.1 (C-3), 127.0 (C-4), 143.2 (C-5), 150.7 (C=NOH) and 151.8 (C-2).

\{2-[1-(N-Hydroxyimino)ethyl]furan-4-yl\}methyl dihydrogen phosphate (3b). Colourless oil (91 mg, 85\%); $v / \mathrm{cm}^{-1} 3253(\mathrm{OH}), 1648(\mathrm{HC}=\mathrm{N})$ and $1228(\mathrm{P}=\mathrm{O}) ; \delta_{\mathrm{H}} / \mathrm{ppm}\left(400 \mathrm{MHz} ; \mathrm{DMSO}-d_{6}\right) 2.37\left(3 \mathrm{H}, \mathrm{s}, \mathrm{CH}_{3}\right), 3.90(2 \mathrm{H}, \mathrm{s}, 2 \mathrm{x}$ $\mathrm{OH}), 5.11\left(2 \mathrm{H}, \mathrm{d}, \mathrm{J} 2.0 \mathrm{~Hz}, \mathrm{OCH}_{2}\right), 7.12(1 \mathrm{H}, \mathrm{s}, 5-\mathrm{H}), 7.32(1 \mathrm{H}, \mathrm{s}, 3-\mathrm{H})$ and $8.93(1 \mathrm{H}, \mathrm{s}, \mathrm{NOH}) ; \delta \mathrm{c} / \mathrm{ppm}(100 \mathrm{MHz} ;$ DMSO-d $\left.d_{6}\right) 13.2\left(\mathrm{CH}_{3}\right), 62.5\left(\mathrm{~d}, \mathrm{~J}_{\mathrm{P}-\mathrm{C}}=6.3 \mathrm{~Hz}, \mathrm{OCH}_{2}\right), 110.2(\mathrm{C}-3), 127.1(\mathrm{C}-4), 143.7(\mathrm{C}-5), 150.8(\mathrm{C}=\mathrm{NOH})$ and 153.3 (C-2); (Found: $\mathrm{C}, 35.84 ; \mathrm{H}, 4.31 ; \mathrm{N}, 5.32 \%$. $\mathrm{C}_{7} \mathrm{H}_{10} \mathrm{NO}_{6} \mathrm{P}$ requires $\mathrm{C}, 35.76 ; \mathrm{H}, 4.29 ; \mathrm{N}, 5.29 \%$ ).

\{2-[1-(N-Hydroxyimino)-3,3-dimethylbutyl]furan-4-yl\}methyl dihydrogen phosphate (3c). Colourless oil (87 $\mathrm{mg}, 83 \%) ; \mathrm{v} / \mathrm{cm}^{-1} 3260(\mathrm{OH}), 1678(\mathrm{HC}=\mathrm{N})$ and $1229(\mathrm{P}=\mathrm{O}) ; \delta_{\mathrm{H}} / \mathrm{ppm}\left(400 \mathrm{MHz} ; \mathrm{DMSO}-d_{6}\right) 1.12\left(9 \mathrm{H}, \mathrm{s}, 3 \times \mathrm{CH}_{3}\right)$, $1.83\left(2 \mathrm{H}, \mathrm{s}, \mathrm{CH}_{2} \mathrm{C}=\mathrm{N}\right), 2.31(2 \mathrm{H}, \mathrm{s}, 2 \times \mathrm{OH}), 5.09\left(2 \mathrm{H}, \mathrm{d}, \mathrm{J} 1.6 \mathrm{~Hz}, \mathrm{OCH}_{2}\right), 7.17(1 \mathrm{H}, \mathrm{s}, 5-\mathrm{H}), 7.32(1 \mathrm{H}, \mathrm{s}, 3-\mathrm{H})$ and $10.41(1 \mathrm{H}, \mathrm{s}, \mathrm{NOH}) ; \delta_{\mathrm{c}} / \mathrm{ppm}\left(100 \mathrm{MHz}\right.$; DMSO-d 6 ) $29.0\left(3 \times \mathrm{CH}_{3}\right), 32.6\left(\mathrm{C}-3^{\prime}\right), 36.3\left(\mathrm{C}-2^{\prime}\right), 62.3\left(\mathrm{~d}, \mathrm{~J}_{\mathrm{P}-\mathrm{C}} 6.6 \mathrm{~Hz}\right.$, $\mathrm{OCH}_{2}$ ), 110.8 (C-3), 127.5 (C-4), 142.7 (C-5), 150.3 (C=NOH) and 152.2 (C-2); (Found: C, 45.29; H, 6.31; N, 4.79\%. $\mathrm{C}_{11} \mathrm{H}_{8} \mathrm{NO}_{6} \mathrm{P}$ requires $\left.\mathrm{C}, 45.36 ; \mathrm{H}, 6.23 ; \mathrm{N}, 4.81 \%\right)$.

\section{Molecular Docking Protocols}

The receptors used included $E c D X R 2 E^{24}$ (both chains $A$ and $B$ from the crystal structure) and 1Q0L, and PfDXR structures $3 A U A^{44}$ and $3 A U 9^{44}$ (both chains $A$ and $B$ ) together with a homology model ${ }^{43}$ (a PfDXR structure created using an EcDXR structure $100 Q^{45}$ as one of three templates). The structures 3a-c and 10a-c and, in some cases, the prodrug structures (9a-c and 11a-c) were used as ligands for the molecular docking. 
For all structures, all permutations of stereochemistry ( $E / Z$ with respect to the oxime) and protonation states (of the oxime and the phosphate moieties - including both stereoisomers for asymmetric protonation) were generated. These structures were optimized at the $\omega \mathrm{B} 97 \times \mathrm{D} / 6-31+\mathrm{G}(2 \mathrm{~d}, \mathrm{p})$ level prior to molecular docking. In each case, the permutation of the structure resulting in the lowest (best) binding energy was retained as the best binding complex. For rigid docking all residues in the receptor were inflexible while the ligand conformation was explored. For flexible docking the specified flexible residues were for 1Q0L (ASP150, SER151, GLU152, SER222, ASN227, LYS228, GLU231, TRP212); 2EGH (ASP149, SER150, GLU151, SER221, ASN226, LYS227, GLU230, TRP211); 3AUA and 3AU9 (ASP231, SER232, GLU233, SER306, ASN311, LYS312, GLU315, TRP296) and for the PfDXR homology model (ASP160, SER161, GLU162, SER235, ASN240, LYS241, GLU244, TRP225). Molecular docking using Autodock $4.2^{23}$ utilized 100 parallel Lamarckian Genetic Algorithm runs, for a maximum of 4500000 calculations together with a maximum of 27000 generations, with a population size of 150 . The crossover rate was 0.8 and the mutation rate was 0.02 . For the flexible receptor Autodock Vina ${ }^{42}$ and QuickVina-W $W^{46}$ were both used for a search area of $22 \AA$ around the active site, with the exhaustiveness set to 512. For rigid docking Autodock Vina ${ }^{4}$ was used and the exhaustiveness was set to 512 . Visualization was effected in BIOVIA Discovery Studio Visualizer version 17.12.10. ${ }^{49}$

\section{Acknowledgements}

The authors thank Rhodes University for a bursary (to M.K.M.), the South African Medical Research Council (MRC) and Rhodes University for generous financial support, and the Centre for High Performance Computing (CHPC project CHEM0802) at the University of Cape Town for computational time.

\section{Supplementary Material}

Supplementary material related to this article, including Nuclear Magnetic Resonance $\left({ }^{1} \mathrm{H}\right.$ and $\left.{ }^{13} \mathrm{C} N M R\right)$ and in silico docking data are available in the online version of the text.

\section{References}

1. World Health Organisation (WHO) World Malaria Report 2018. ISBN: 9789241565653.

2. Greenwood B. M.; Bojang K., Whitty C. J. M.; Targett G. A. T. The Lancet 2005, 365, 1487-1498. https://doi.org/10.1016/S0140-6736(05)66420-3

3. Trig P. I. ; Kondrachine A. V., The Current Global Malaria Situation. In Malaria, Parasite Biology, Pathogenesis, and Protection; Sherman, I. W., Ed., American Society for Microbiology: Washington, DC, 1998, pp 11-21.

4. Hemingway J.; Ranson H. Annu. Rev. Entomol. 2000, 45, 371-391. https://doi.org/10.1146/annurev.ento.45.1.37

5. French N.; Nakiyingi J.; Lugada E.; Watera C.; Whitworth J. A. G.; Gilks C. F. AIDS 2001, 15, 899-906. https://doi.org/10.1097/00002030-200105040-00010 
6. Whitworth J.; Morgan D.; Quigley M.; Mayanja B.; Eotu H.; Omoding N.; Okongo M.; Malamba S.; Ojwiya A. The Lancet 2000, 356, 1051-1056. https://doi.org/10.1016/s0140-6736(05)71332-5 PMID: 11213125

7. Van Geertruyden J. P.; D’Alessandro U. Trends in Parasitology 2007, 23, 465-467. https://doi.org/10.1016/i.pt.2007.08.006

8. Milhous W. K.; Kyle D. E. Introduction to the Modes of Action of and Mechanisms of Resistance to Antimalarials. In Malaria, Parasite Biology, Pathogenesis, and Protection; Sherman, I. W., Ed.; American Society for Microbiology: Washington, DC, 1998, pp. 303-311.

9. Nosten F.;White N. J. Am. J. Trop. Med. Hyg., 2007, 77, 181-192.

https://doi.org/10.4269/ajtmh.2007.77.181

10. Singh N.; Cheve G.; Avery M. A.; McCurdy C. R. Curr. Pharm. Des. 2007, 13, 1161-1177. https://doi.org/10.1016/i.ejmech.2007.01.024

11. Wiesner J.; Jomaa H. Curr. Drug Targets 2007, 8, 3-13. https://doi.org/10.2174/13894500777931551

12. Cassera M. B.; Gozzo F. C.; D’Alexandri F. L.; Merino E. F.; del Portillo H. A.; Peres V. J.; Almeida I. C.' Eberlin M. N.; Wunderlich G.; Wiesner J.; Jomaa H.; Kimura E. A.; Katzin A. M. J. Biol. Chem. 2004, 279, 5174951759. https://doi.org/10.1074/ibc.M408360200

13. Wiesner J.; Borrmann S.; Jomaa, H. Parasitol. Res. 2003, 90, S71-S76. https://doi.org/10.1007/s00436-002-0770-9

14. Devreux V.; Wiesner, J; Van Der Eycken J.; Jomaa, H.; Van Calenbergh S. Bioorg. Med. Chem. Lett. 2007, 17, 4920-4923.

https://doi.org/10.1016/j.bmcl.2007.06

15. Adeyemi, C. M.; Faridoon; Isaacs, M.; Mnkandhla, D.; Hoppe, H. C.; Krause, R. W. M.; Kaye, P. T. Bioorg. Med. Chem. 2016, 24, 6131-6138, and references cited therin https://doi.org/10.1016/j.bmc.2016.04.021

16. Adeyemi, C. M.; Klein, R.; Isaacs, M.; Mnkandhla, D.; Hoppe, H. C.; Krause, R. W. M.; Kaye, P. T. Tetrahedron 2017, 73, 1661-1667. https://doi.org/10.1016/i.tet.2017.01.045

17. Adeyemi, C. M.; Hoppe, H. C.; Isaacs, M.; Klein, R.; Lobb, K. A.; Kaye, P. T. Tetrahedron 2019, 75, $2371-2378$. https://doi.org/10.1016/i.tet.2019.02.003

18. Adeyemi, C.M.; Conibear, A.C.; Mutorwa, M.K.; Nokalipa, I.; Isaacs, M.; Mnkandhla, D.; Hoppe, H.C.; Lobb, K.A.; Klein, R.; Kaye, P.T. Bioorg. Chem. In press. (Volume 101 August 2020 Article 103947) https://doi.org/10.1016/j.bioorg.2020.103947

19. Devreux V.; Wiesner, J.; Jomaa, H.; Rozenski J.; Van Der Eycken J.; Van Calenbergh S. J. Org. Chem. 2007, 72, 3783-3789.

https://doi.org/10.1021/jo0700981

20. Devreux V.; Wiesner J.; Goeman J. L.; Van Der Eycken J.; Jomaa, H.; Van Calenbergh S. J. Med. Chem. 2006, 49, 2656-2660.

https://doi.org/10.1021/jm051177c

21. Verbrugghen T.; Cos P.; Maes L.; Van Calenbergh S. J. Med. Chem. 2010, 53, 5342-5346. https://doi.org/10.1021/jm100211e

22. Mutorwa, M.K. PhD thesis, Rhodes University, 2011. 
23. Morris, G. M.; Huey, R.; Lindstrom, W.; Sanner, M. F.; Belew, R. K.; Goodsell, D. S.; Olson, A. J. J. Comput. Chem. 2009, 16, 2785-91.

https://doi.org/10.1002/jcc.21256

24. Yajima S.; Hara K.; Lino D.; Sasaki Y.; Kuzuyama T.; Ohsawa K.; Seto H. Acta. Crystallogr. Sect. F: Struct. Biol. Cryst. Comm. 2007, 63, 466-470. https://doi.org/10.1107/S1744309107024475

25. Belen'kii L. I.; Kim T. G.; Suslov I. A.; Chuvylkin N. D. Arkivoc 2003, (xiii), 59-67. https://doi.org/10.3998/ark.5550190.0004.d08

26. Kutney J. P.; Hanssen H. W.; Nair G. V. Tetrahedron 1971, 27, 3323-3330. https://doi.org/10.1016/S0040-4020(01)97744-0

27. Thomas A. D.; Asokan J.; Asokan C. V.; Tetrahedron 2004, 60, 5069-5076. https://doi.org/10.1016/i.tet.2004.04.017

28. Rai L. M. K.; Musad E. A.; Jagadish R. L.; Shivakumar K. N. Synth. Commun. 2011, 41, 953-955. https://doi.org/10.1080/00397911003707139

29. Sarvari H. M.; Sharghi H. Helv. Chim. Acta, 2005, 88, 2282-2287. https://doi.org/10.1002/hlca.200590162

30. Linda P.; Marino G. Tetrahedron 1967, 23, 1739-1743. https://doi.org/10.1016/S0040-4020(01)82573-4

31. Ciranni G. Tetrahedron Lett. 1971, 41, 3833-3836. https://doi.org/10.1016/S0040-4039(01)97301-0

32. Hartough H. D.; Kosak A. I. J. Am. Chem. Soc. 1947, 69, 1012. https://doi.org/10.1021/ja01197a010

33. For the acetylation of the furan derivative $\mathbf{5}$, acetic anhydride was used as the acylating agent, rather than acetyl chloride, since a weaker acid $(\mathrm{AcOH})$ is liberated during the reaction and better reaction yields have been reported by Clementi S.; Linda P.; Vergoni M. Tetrahedron 1971, 27, 4667-4672 https://doi.org/10.1016/S0040-4020(01)98173-6

34. Stumpp M. C.; Schmidt R. R. Tetrahedron 1986, 42, 5941-5948. https://doi.org/10.1016/S0040-4020(01)96076-4

35. Pragnacharyulu P. V.; Abushanab E.,Tetrahedron Lett. 1995, 36, 5507-5510. https://doi.org/10.1016/00404-0399(50)1117Z-

36. Nguyen C.; Kasinathan G.; Leal-Cortijo I.; Musso-Buendia A.; Kaiser M.; Brun R.; Ruiz-Pe'rez L. M.; Johansson N. G.; Gonza'lez-Pacanowska D.; Gilbert I. H. J. Med. Chem. 2005, 48, 5942-5954. https://doi.org/10.1021/jm050111e

37. Srinivas O.; Radhika S.; Bandaru N. M.; Nadimpalli S. K.; Jayaraman N. Org. Biomol. Chem. 2005, 3, 42524257. https://doi.org/10.1039/b506348e

38. Ren R. X.; Ou W. Tetrahedron Lett. 2001, 42, 8445-8446. https://doi.org/10.1016/S0040-4039(01)01851-2

39. Damljanovic I.; Vukicevic M.; Vukicevic R. D. Monatsh. Fur. Chem. 2006, 137, 301-305. https://doi.org/10.1007/s00706-005-0427-3

40. Kad G.L.; Bhandari M.; Kaur J.; Rathee R.; Singh J. Green Chem. 2001, 3, 275. https://doi.org/10.1039/b107356g

41. Kizil M.; Murphy J. A. Tetrahedron 1997, 53, 16847. https://doi.org/10.1016/S0040-4020(97)90251-9 
42. Trott, O.; Olson, A. J. J. Comput. Chem. 2010, 31, 455-461.

43. Goble, J. L.; Adendorff, M. R.; de Beer, T. A. P.; Stephens, L. L. ; Blatch, G. L. Protein Pept. Lett. 2010, 17, 109-120.

https://doi.org/10.2174/092986610789909548

44. Umeda, T. Tanaka, N., Kusakabe, Y., Nakanishi, M., Kitade, Y.; Nakamura, K.T. Sci. Rep. 2011, 1, 9. https://doi.org/10.1038/srep00009

45. Mac Sweeney, A., Lange, R., Fernandes, R.P., Schulz, H., Dale, G.E., Douangamath, A., Proteau, P.J.; Oefner, C. J. Mol. Biol., 2005, 345, 115-127. https://doi.org/10.1016/i.jmb.2004.10.030

46. Hassan, N.M. ; Alhossary, A.A. ; Mu, Y.; Kwoh, C-K., Sci. Rep. 2017, 7, 15451. https://doi.org/10.1038/s41598-017-15571-7

47. Goble' J.L.; Johnson, H.; de Ridder, J.; Stephens, I.L.; Louw, A.; Blatch, G.L.; Boshoff, A. Protein Pept Lett. $=2013,20,115-124$. https://doi.org/10.2174/092986613804725253

48. Tanner D. C. MSc. Thesis, Rhodes University, Grahamstown, 2003.

49. SYSTÈMES, D. (2016). BIOVIA Discovery Studio Dassault Syst mes BIOVIA, Discovery Studio Modeling Environment, Release 2017. Dassault Syst mes 